\title{
Characteristics of Landscape Change Patterns at Three Distinct Stages of the Construction and Operation of the Three Gorges Reservoir From 1986 to 2017
}

\author{
Ruikang Li \\ Beijing Normal University \\ Yangbing Li \\ Chongqing Normal University \\ Bo Li ( $D$ libo@bnu.edu.cn ) \\ Beijing Normal University
}

\section{Research Article}

Keywords: DEM, TGR, landscape, Economic

Posted Date: December 2nd, 2020

DOI: https://doi.org/10.21203/rs.3.rs-112382/v1

License: (c) (1) This work is licensed under a Creative Commons Attribution 4.0 International License. Read Full License

Version of Record: A version of this preprint was published at Scientific Reports on April 29th, 2021. See the published version at https://doi.org/10.1038/s41598-021-87732-8. 


\title{
Characteristics of landscape change patterns at three distinct stages of the construction and operation of the Three Gorges Reservoir from 1986 to 2017
}

\author{
Ruikang $\mathrm{Li}^{1}$, Yangbing $\mathrm{Li}^{2,3}$, and $\mathrm{Bo} \mathrm{Li}^{1}{ }^{*}$ \\ ${ }^{1}$ Faculty of Geographical Science, Beijing Normal University, Beijing, 100875, China \\ ${ }^{2}$ College of Geography and Tourism, Chongqing Normal University, Chongqing, 401331, China \\ ${ }^{3}$ Affiliation, department, city, postcode, country \\ *corresponding. libo@bnu.edu.cn
}

\begin{abstract}
Analyses of landscape change patterns that are based on elevation and slope can not only provide reasonable interpretations of landscape patterns but can also help to reveal evolutionary laws. As a complex geographical unit, the ecosystem environment in the middle reach of the Yangtze River has experienced great changes due to the construction of the Three Gorges Reservoir (TGR) and its associated human activities. Here, based mainly on a digital elevation model (DEM) and remotely sensed images from 1986, 2000, 2010, and 2017 and by using GIS technology, buffer analysis, landscape element change and landscape pattern indices, the spatial and temporal evolution characteristics of different elevations, slopes, and buffer landscape types were analyzed in a typical watershed, as well as an evolutionary model of the landscape pattern. The results indicated that (1) the landscape elements along the land classification and buffer zone that were influenced by the TGR construction have undergone a phased change, with the period 2000-2010 being the most dramatic period of landscape evolution during the impoundment period; (2) landscape type shifts from human-dominated farmland to nature-driven forestland and shrub-land as elevations, slopes and buffer distances increased. The landscape has shifted from diversity to relative homogeneity. (3) land types and buffer zones have exhibited a significant effect on the landscape pattern index, which is reflected in the differences in landscape type indices for spatial extension and temporal characteristics. The results of this study illustrate the pronounced effect of the TGR on landscape patterns, and these findings will elucidate the scientific basis and provide a reference for sustainable land resource management in the study region.
\end{abstract}

\section{Introduction}

A natural system is an interconnected and interacting ecosystem. Economic development is closely related to the protection of the ecological environment. A good ecological environment is an important carrier of economic development. More than 58,000 massive reservoirs had been built worldwide by $2015^{1}$ and approximately $45 \%$ of these had been constructed in China ${ }^{2}$. As an effective method for water resource utilization and regulation, dams have made important contributions to social and economic development. More rivers have been altered, and large-scale water conservation projects ${ }^{3,4}$ have been undertaken to satisfy the demands of rapid socioeconomic development ${ }^{5,6}$. Large dams can affect landscape distributions by impounding water for prolonged periods. The construction and operation of large reservoirs have profoundly changed the delivery of riverine material ${ }^{7}$ and have caused unprecedented ecological and environmental challenges upstream and downstream ${ }^{8}$, and in recent decades, these changes have attracted extensive attention from experts and scholars around the world ${ }^{9,10,11,12}$. As especially frequent human activities, land inundation, flow manipulation, and fragmentation triggered by reservoir construction ${ }^{13}$ have crucial environmental impacts: unavoidable crop production losses ${ }^{14}$, changes in hydrological conditions ${ }^{15}$, soil erosion ${ }^{16}$, increases in population and pollution inputs ${ }^{17}$, which ultimately lead to changes in landscape patterns. In the context of global climate change, dam construction and its ecological effects are complex, potential, spatial, cumulative and unpredictable ${ }^{18}$. Quantifying the landscape ecological impact of reservoirs is essential for developing appropriate strategies to reduce adverse impacts on regional environments. Land-use-based landscape ecological security assessments play an important role in the construction of ecological security patterns ${ }^{19}$.

Landscape patterns generally refer to the spatial patterns of landscapes and patterns of spatial distribution, structure and configuration of spatial components with different sizes, shapes and attributes ${ }^{20}$. These patterns reflect the state of a region's natural environment and influence the stability and order of the ecosystem ${ }^{21}$. The central issue is to improve the integration of landscape indices with ecological processes. The gradient effect is evident for different elevations, slopes and topographic fluctuations ${ }^{22}$. Physical factors, including elevation and slope, are among the many factors that have significant impacts on land use distributions ${ }^{23}$. Geomorphic conditions are the most critical factor for determining the intensity of human transformations of landscapes. Landscape conditions form landscape evolution patterns that reflect not only the extent of human influence on natural ecosystems but also the responses of human activities triggered by landscape conditions ${ }^{24}$. 
As one of the largest dam reservoirs in the world, the TGR is located in the middle reaches of the Yangtze River ${ }^{25}$ and is a fragile natural ecosystem ${ }^{26,27}$ with complex and rugged topography that has a significant impact on the eutrophication of water in the tributary bays of the TGR ${ }^{28}$. The protection of the ecology and environment in the TGRA plays a crucial role in the green development of the Yangtze River Economic Zone ${ }^{29}$. With the construction of the Three Gorges Dam (TGD) and several increases of water levels, many areas upstream of the reservoir have been inundated ${ }^{30}$. Landscape patterns have also changed greatly with varying degrees of anthropogenic disturbance ${ }^{31}$. Population migration, agricultural surface pollution, and soil erosion have led to land cover changes ${ }^{32,33}$. In addition, approximately three-quarters of the Three Gorges Reservoir Area (TGRA) is mountainous, and approximately $24.74 \%$ of the area is steep and unstable with slopes greater than $25^{\circ 34}$. In response to local ecological changes, the Chinese government has actively implemented various large-scale ecological policies and strategies, such as the Forest Projects ${ }^{35}$ and Special Water Management Plan $^{36}$. Land use and landscape patterns have changed significantly over the past 30 years to maintain the stability of natural ecosystems and gene pools ${ }^{37}$.

In recent decades, there has been an abundance of national and international research on landscape evolution patterns, as is evidenced by qualitative and quantitative analyses using GIS and RS techniques in conjunction with landscape pattern indices ${ }^{38}$ that include the relationships between landscape and soil erosion ${ }^{39}$, ecological security patterns ${ }^{40}$, and granularity of landscape pattern effects $^{41}$, among others. As research has progressed, some scholars have introduced landscapes into geography to study the relationship between landscape change and landforms ${ }^{42}$, and the scale of research has gradually shifted from comprehensive evaluations at large scales to in-depth studies at small scales. Moreover, most studies have lacked the dynamics of evaluation results over long time periods. At this stage, many researchers have studied the evolution of landscape patterns in the TGRA before and after water storage and have focused on spatial granularity effects ${ }^{43}$, effects of forest restoration on soil erosion ${ }^{44}$ and cropland patterns and driving forces ${ }^{43}$.

While past work has mainly focused on landscape change and its evolution characteristics, little information is available on the relationship between landforms (based on elevations and slope gradients) and evolution of landscape patterns. Landscapes can vary under different landform conditions ${ }^{42}$, and the landform context has a significant influence on landscape pattern evolution and human disturbance ${ }^{45}$. The land cover and landscape types in the TGRA have shown great variations due to the influence of water conservancy construction. Therefore, this paper aims to investigate the evolution of different landscape patterns based on elevation and slope zone reclassification in a typical watershed of Chongqing under the context of the TGP construction and operation. The intention is to provide referential significance for land use planning, establishment of ecological patterns and environmental protection in the core of the TGRA.

\section{Background: Construction timeline of the TGP}

In China, the TGP began in 1993 and was completed in 1997 on the upper trunk of the Yangtze River ${ }^{46}$, which is the largest hydroelectric project ever conducted ${ }^{47}$, to accommodate flood control, irrigation, increased navigation and power generation needs ${ }^{48,49}$. Hydropower construction was completed in $2002^{34}$, reservoir filling was initiated in 2003 and impoundment was completed in $2010^{50}$. By June 2003, the water level was expected to increase to $135 \mathrm{~m}$ ASL (above sea level), and the first filling stage was completed in $2003^{51}$. The reservoir level reached $156 \mathrm{~m}$ ASL in October 2006. In October 2010, the TGR reached its normal storage level of $175 \mathrm{~m}$ ASL for the first time ${ }^{52}$, and approximately $240 \mathrm{~km}^{2}$ of citrus and farmland was inundated. Water levels of the TGR are maintained between $145 \mathrm{~m}$ ASL from October to March and at $175 \mathrm{~m}$ ASL from April to September ${ }^{53,54}$. By the end of 2010, the TGP had been completed, and the entire reservoir area entered the Post-Three Gorges era ${ }^{28}$. The formation of the TGRA is a direct consequence of the $\mathrm{dam}^{55}$. According to previous relevant studies, the TGRA can be divided into three significant time periods: the construction period, impoundment period and Post-Three Gorges era ${ }^{56,57}$. Considering the actual situation of the hinterland basin of the reservoir area and the difficulty of data acquisition, this study is divided into three phases: 1986 2000, 2000 2010 and 2010 2017 (Fig. 1).

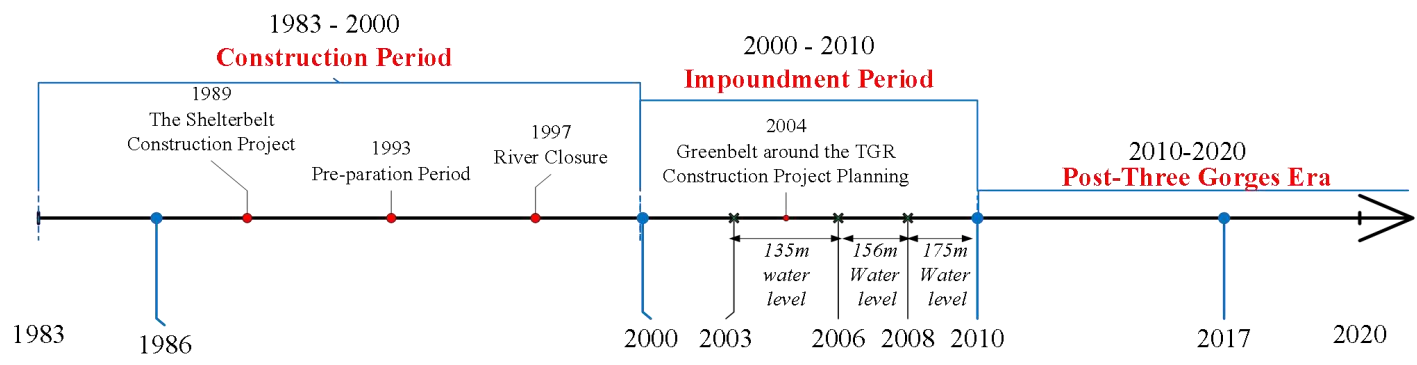

Figure 1. Construction timeline of the TGP.

\section{Study area and data source}

\section{Study area}

TR, MR, and DR in the hinterland of the TGRA were used as case studies (Fig. 2). The study area extends over $31^{\circ} 02^{\prime} 39^{\prime \prime} \sim 31^{\circ}$ 
$44^{\prime} 01^{\prime \prime} \mathrm{N}, 108^{\circ} 37^{\prime} \sim 110^{\circ} 09^{\prime} 05^{\prime \prime} \mathrm{E}$ with a total area of $7,938 \mathrm{~km}^{2}$. It has a northern subtropical humid monsoonal climate, and the prevailing soil types are yellow-brown and purple soils. This area belongs to the Chongqing section of the TGRA, covers four counties, including Yunyang, Fengjie, Wushan, and Wuxi and is the core area for ecological protection and development in northeastern Chongqing and is also a fragile and ecologically sensitive area of the TGRA with high mountains and steep slopes ${ }^{17}$. The watershed belongs to the first tributary of the north bank of the Yangtze River; TR, MR, and DR are adjacent to each other and have different natural social and economic backgrounds. DR is a karst watershed, MR is a combined karst and non-karst watershed, and TR is heavily influenced by coal and other industrial wastes with many factories, coal mines, and construction sites. Our study area is representative of the contemporary landscape and is subject to natural and anthropogenic gradients and disturbances.
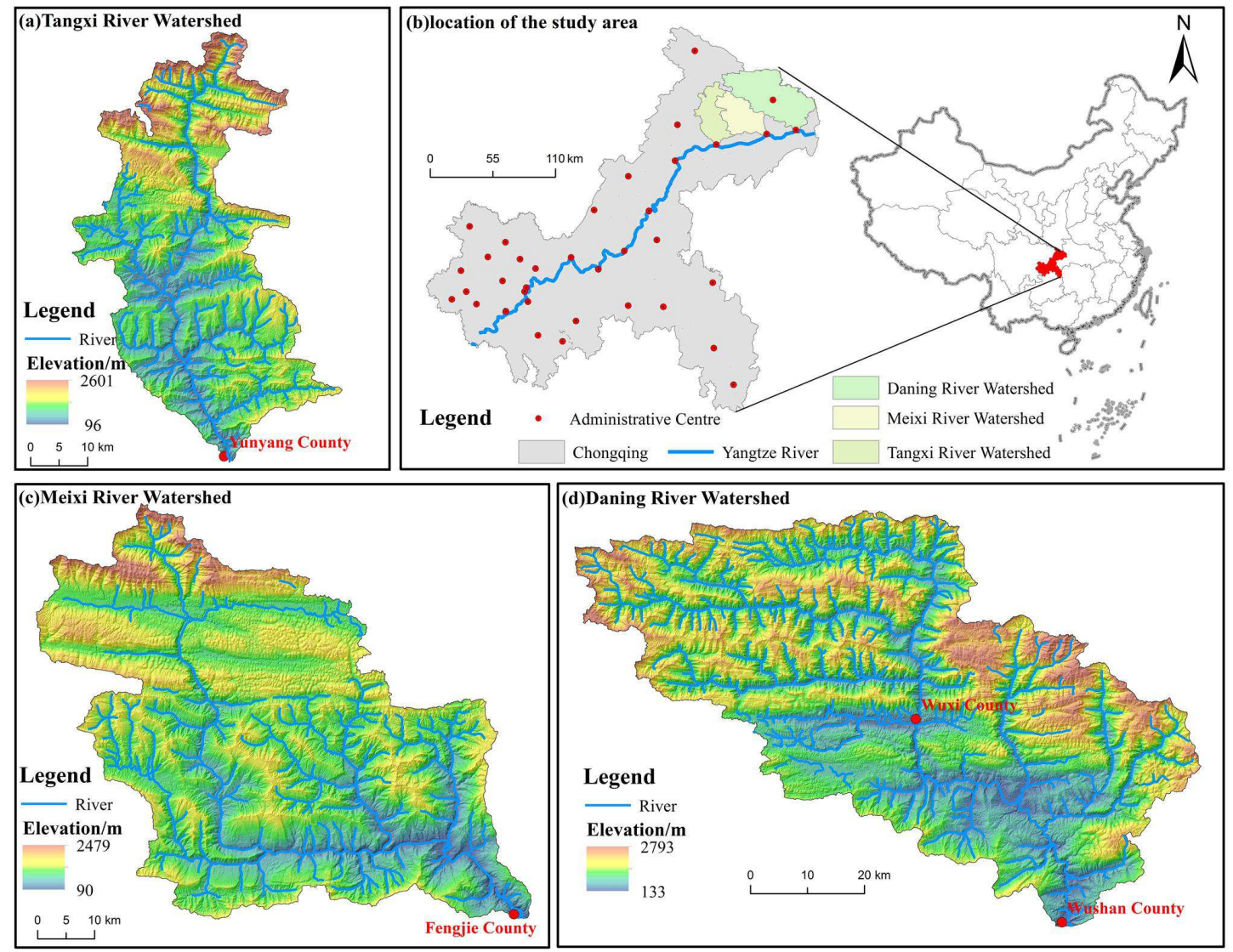

Figure 2. Location and topography of the study area in the Three Gorges Reservoir Area

\section{Data source and processing}

Our basic data sources include multiemporal satellite datasets and a digital elevation model (DEM). (1) Land use maps for 1986, 2000, 2010 and 2017 (Fig. 3) were obtained from Landsat Thematic Mapper (TM) and Enhanced Thematic Mapper-plus $(\mathrm{ETM}+)$ images with $30 \mathrm{~m}$ resolution using nonlinear classification and artificial visual interpretation methods. The regional landscapes were divided into dryland, paddy field, forestland, shrubland, grassland, water area, built-up areas, and unused land ${ }^{58}$. To meet the needs of the study, land use data from 1986, 2000 and 2010 were rigorously compared with data provided by the "data center for environmental and ecological sciences in western China" of the National Natural Science Foundation of China. For the 2017 land-use data, we strictly compared them with the high-resolution images from resource satellites with a resolution of $2.5 \mathrm{~m}$ during the interpretation process. Currently, we are using a combination of random sampling checks and field surveys to ensure data accuracy, and both have an accuracy rate of $92 \%$, which meets the needs of this study. (2) Elevation and slope maps are based on 30 $\mathrm{m}$ resolution DEM data, which were downloaded from the CAS Resources and Environmental Science Data Center (http://www.resdc.cn). (3) Watershed vector boundaries were extracted from the DEM data with the hydrology tool in ArcGIS 10.2. 

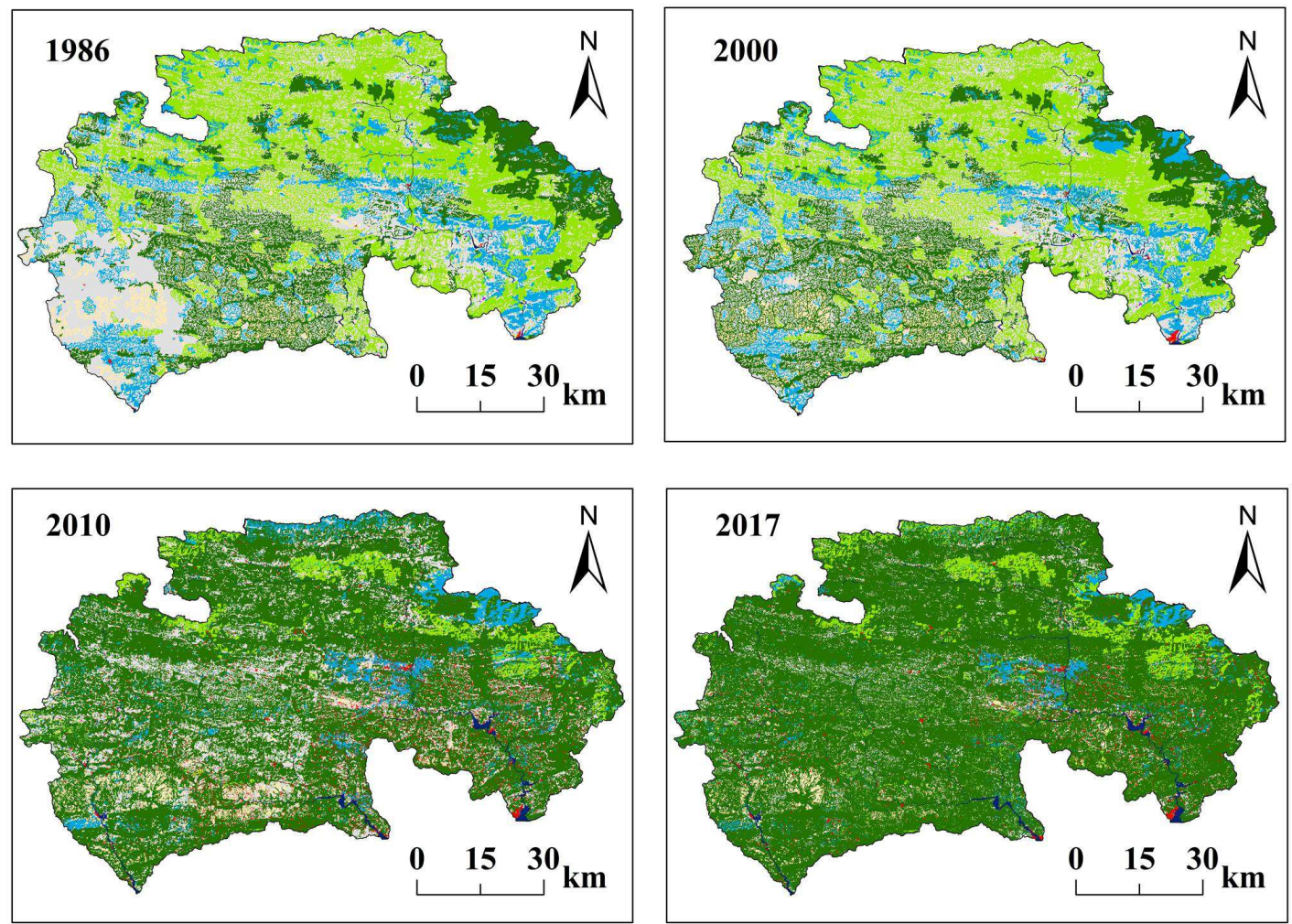

Legend

\section{Dryland}

Grassland
Paddy Field

Water

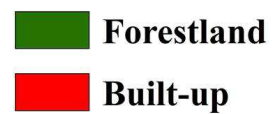

Shrubland

Unused Land

Figure 3. Spatial division of landscape type in watershed from 1986 to 2017

\section{Results analysis}

\section{Changing speeds $(K)$ and trends $(P)$ of landscape elements for different land types}

We overlaid the land use map with the landform classification data by using the intersection tool in ArcGIS 10.2 software to obtain the landscape elements for different land types and then calculated the $K$ and $P$ values based on the methods described in Formula (1) and (2); and the results are shown in Fig. 4.

Fig. 4a exhibits the changes in $K$-values along landforms for each landscape type. From 1986 to 2000, the $K$-values of each landform did not change significantly while the area of forestland increased significantly in valleys with slopes within $15^{\circ}$. From 2000 to 2010, the $K$-values for altitude and slope changed differently. Waters and built-up areas showed clear increasing trends at elevation gradients below $1,000 \mathrm{~m}$, while forestland and waters showed the most pronounced increases in each slope zone. This dramatic increase was mainly due to the rise in reservoir levels and implementation of the national migration policy. As a result of urbanization, the total amount of built-up areas exhibited an upward trend from 2010 to 2017 in the middle mountainous areas where the elevations were higher than $1,500 \mathrm{~m}$.

Fig. 4b represents the trend of $P$ in landscape type along land classification at each time point. In the period 1986 2000, the landscape trend changed slightly except in valley areas. In this region, forestland, water and built-up areas all expanded in an "upward" fashion. From 2000 to 2010, land use trends varied for elevation and slope. Cultivated land increased for slopes less than $8^{\circ}$; in areas below $1,000 \mathrm{~m}$ elevation and with slopes less than $15^{\circ}$, settlements were the dominant landscape, and in both low and steep slope areas, water sources increased significantly as the water level rose. From 2010 to 2017, the landscape trends changed slightly, except in the valley and mid-mountain areas. In the valley areas, shrublands expanded in an "ascending" fashion. For the mid-hills, the built-up area expanded significantly in an "ascending" state.

In general, landscape elements in the watershed change at different rates and trends along elevation, slopes and buffers, and the changes are phased and exhibit a process that changes from quantitative to qualitative. The period from 2000-2010 experienced the most intense landscape evolution during the impoundment period. 

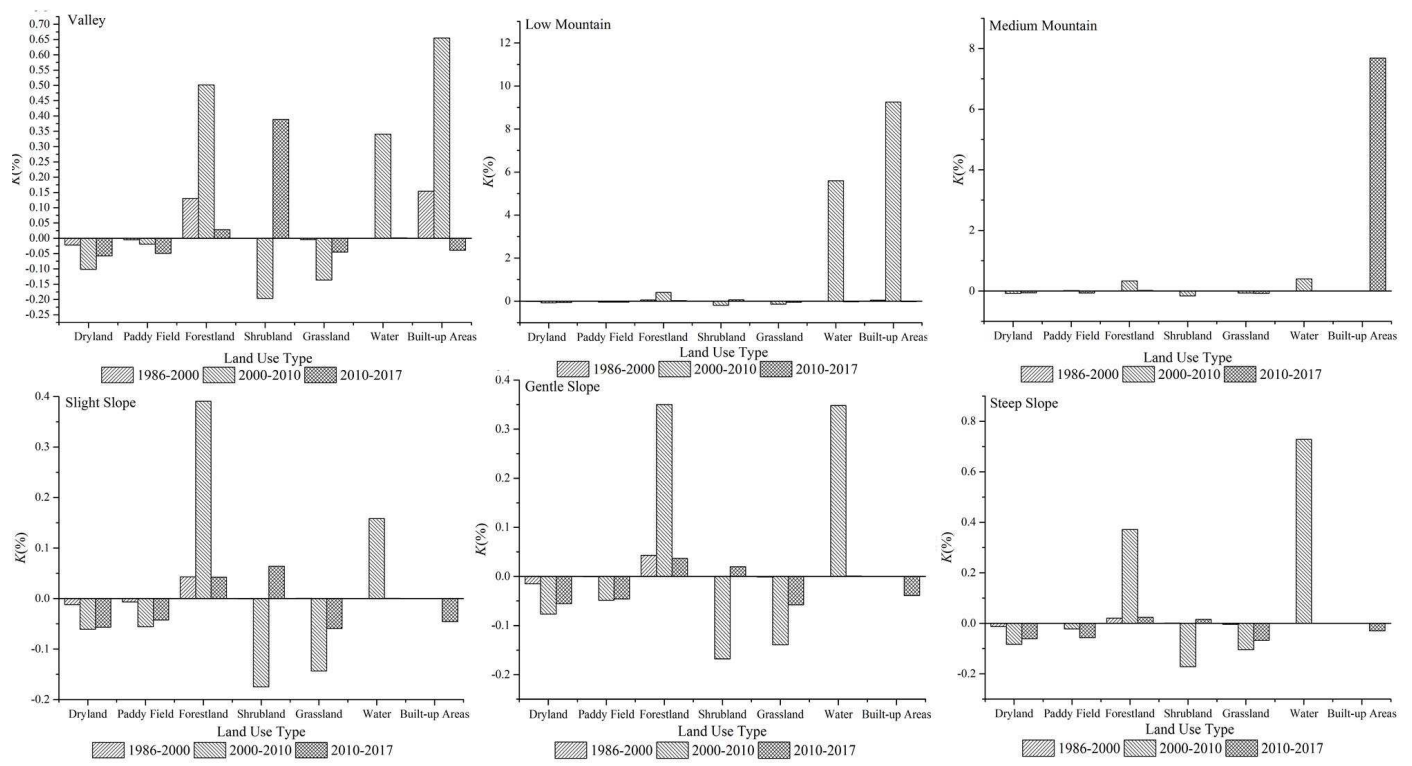

Figure 4a. Speed of different landscape types for different land types of the watersheds
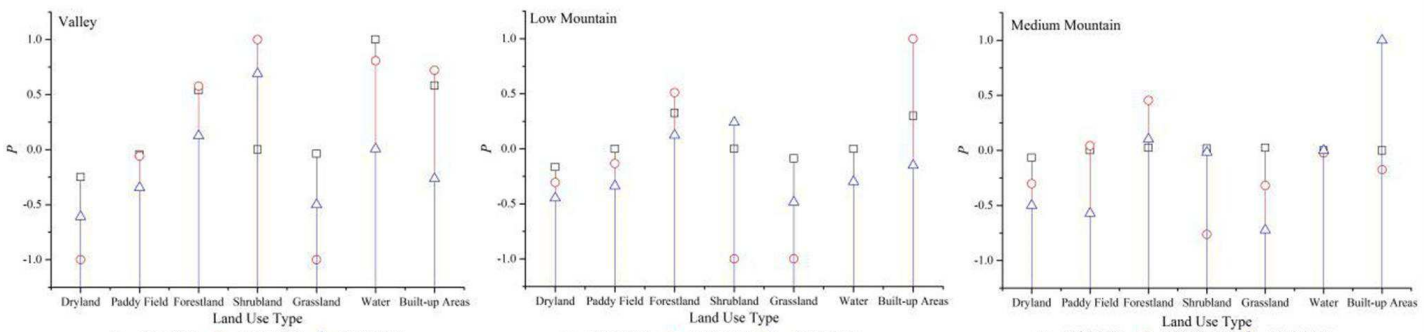

[. 1986-2000 $\quad \mathrm{C}^{2000-2010} \triangle 2010-2017$
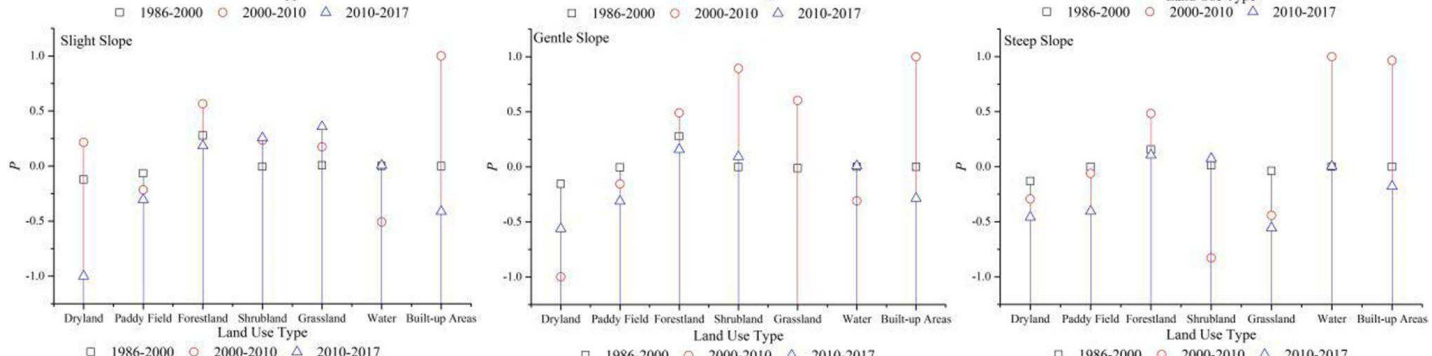

Figure 4b. Trend of different landscape types for different landforms of the watershed

Analysis of changes in the level of land use $(L A)$ in the buffer zones

We used the intersect tool in ArcGIS 10.2 software to overlay the landscape elements of the different landform maps with the watershed buffers and then calculated the $L A$ values based on the method described in Formula (3); and the results are shown in Figs. 5 and 6.

Variations in buffer distance reflect to some extent the variations in upstream and downstream distances. Fig. 5 shows that the land use degree index $(L A)$ of each buffer zone in the basin showed a general downward trend that reached a maximum value for a buffer zone of $30 \mathrm{~km}$ and a minimum value for a buffer zone of $110 \mathrm{~km}$. Within the $30 \mathrm{~km}$ buffer zone, the terrain is relatively flat, dominated by micro-slopes, and influenced by the intensity of human activities, while the degree of development is relatively high.

As illustrated in Fig. 6, the landscape changes in the different land types in different buffer zones of watersheds varied from 1986 to 2017. Within the $30 \mathrm{~km}$ buffer, all land types in TR had the highest landscape synthesis with reduced fluctuations around them, while the landscape synthesis in the MR and DR buffers differed significantly across the different media. For MR, the largest number occurred for a buffer zone of $10 \mathrm{~km}$ during the period of 1986 2000 among each geomorphic type. The $50 \mathrm{~km}$ buffer zone was largest in 2010 for the valley, medium-mountain and steep slope areas, while the $80 \mathrm{~km}$ buffer zone was largest for the low-mountain, slight slope and gentle slope areas. In 2017, except for the gentle slope, the $70 \mathrm{~km}$ buffer zone was largest, while the other geomorphic areas were all largest in the $10 \mathrm{~km}$ buffer zone. The maximum value of the land-use degree index $(L A)$ among the geomorphic areas in DR occurred in different buffer zones. By comparing relevant research results, it was found that the $30 \mathrm{~km}$ buffer zone in TR, $50 \mathrm{~km}$ buffer zone in MR and $10 \mathrm{~km}$ buffer zone in DR were mainly 800 1,000 m above sea level, and the lithology was mainly sandstone and mud shale, which are easily reclaimed for farmland. Human activities were relatively concentrated $^{59}$, so $L A$ was relatively high. 


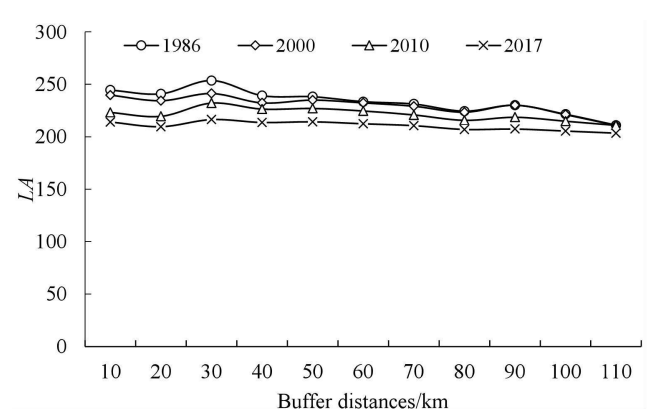

Figure 5. Comprehensive landscape degree index in buffer zone of the watershed
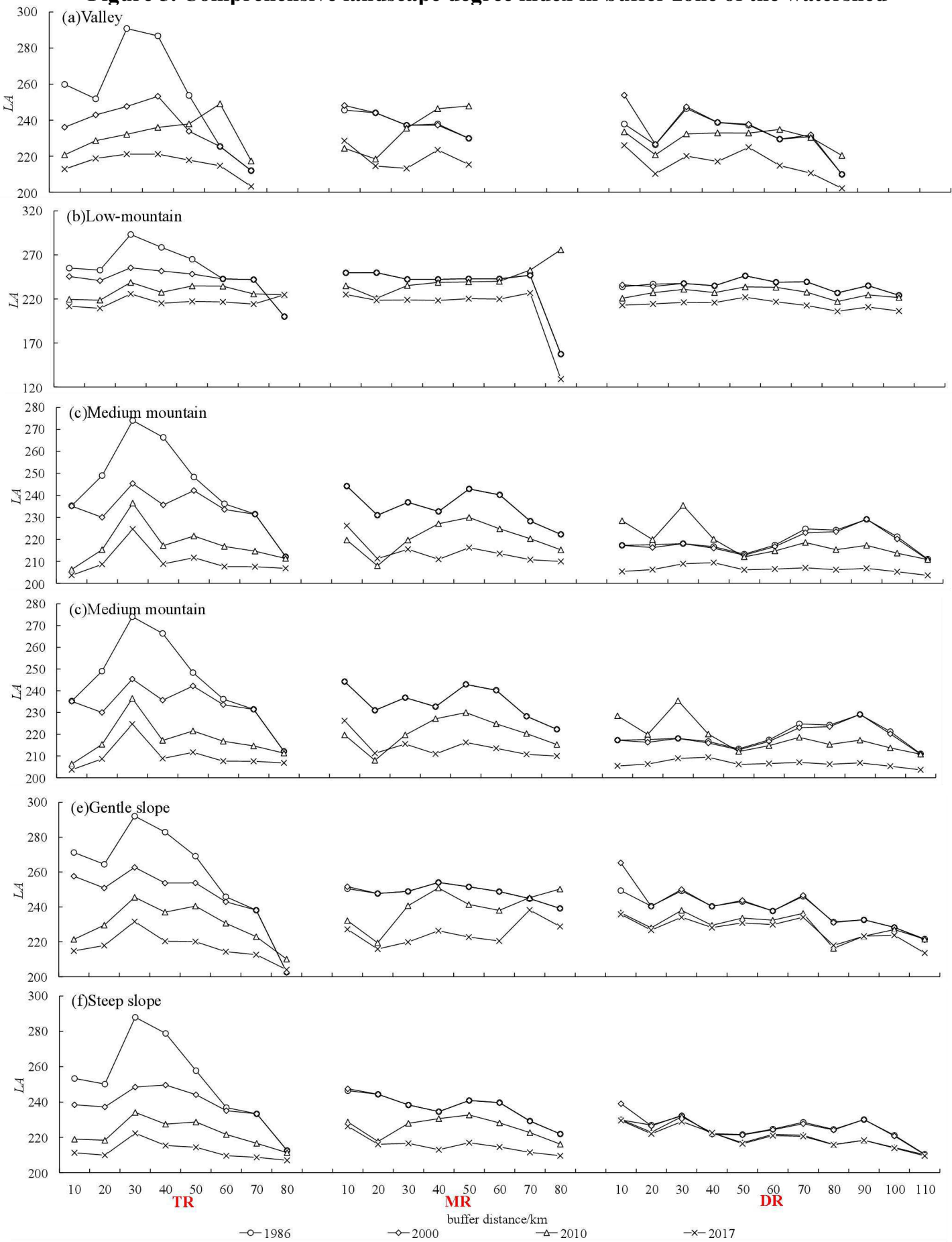

Figure 6. Comparison of LA in different buffer zones of watersheds from 1986 to 2017 
Four landscape indexes(PD, $A I, L S I, S H D I)$ characteristics by buffer analysis

We overlaid the land use map with the buffer data using the intersect tool in ArcGIS 10.2 software to obtain landscape elements with different buffers and then calculated PD, SHDI, AI and LSI values on the FRAGSTATS 4.2.1 platform; and the results are shown in Fig. 7.

Fig. 7 shows that $P D$ and $A I$ both increased at four time points, while $S H D I$ and $L S I$ clearly decreased. In particular, from 1986 to 2000 , the $P D$ values in all three watersheds were less than 2 , and these small values were less affected by the construction of the TGP. After 2000, due to the implementation of ecological migration and circular economic development, there was a significant increase in $P D$ values and a significant decrease in $S H D I$ and $L S I$ values. With increasing buffer distances, $P D$ showed a clear upward trend in MR and DR and increased volatility in TR. During the study period, SHDI showed a decreasing trend as the buffer distance increased. This indicates the transition from a diverse landscape of cultivated land, forest, shrub and grass to a single landscape dominated by forestland in the watershed with the advent of the post Three-Gorges Era. For $A I$ values over 90, landscape aggregation is evident. With increasing buffer distance, the $L S I$ showed an inverted $\mathrm{U}$ trend.

Overall, the landscape pattern characteristics in the watershed changed significantly as a result of TGP progression, with an upward trend in $P D$ and downward trend in $S H D I, A I$ and $L S I$. This may imply an increase in ecosystem quiescence.

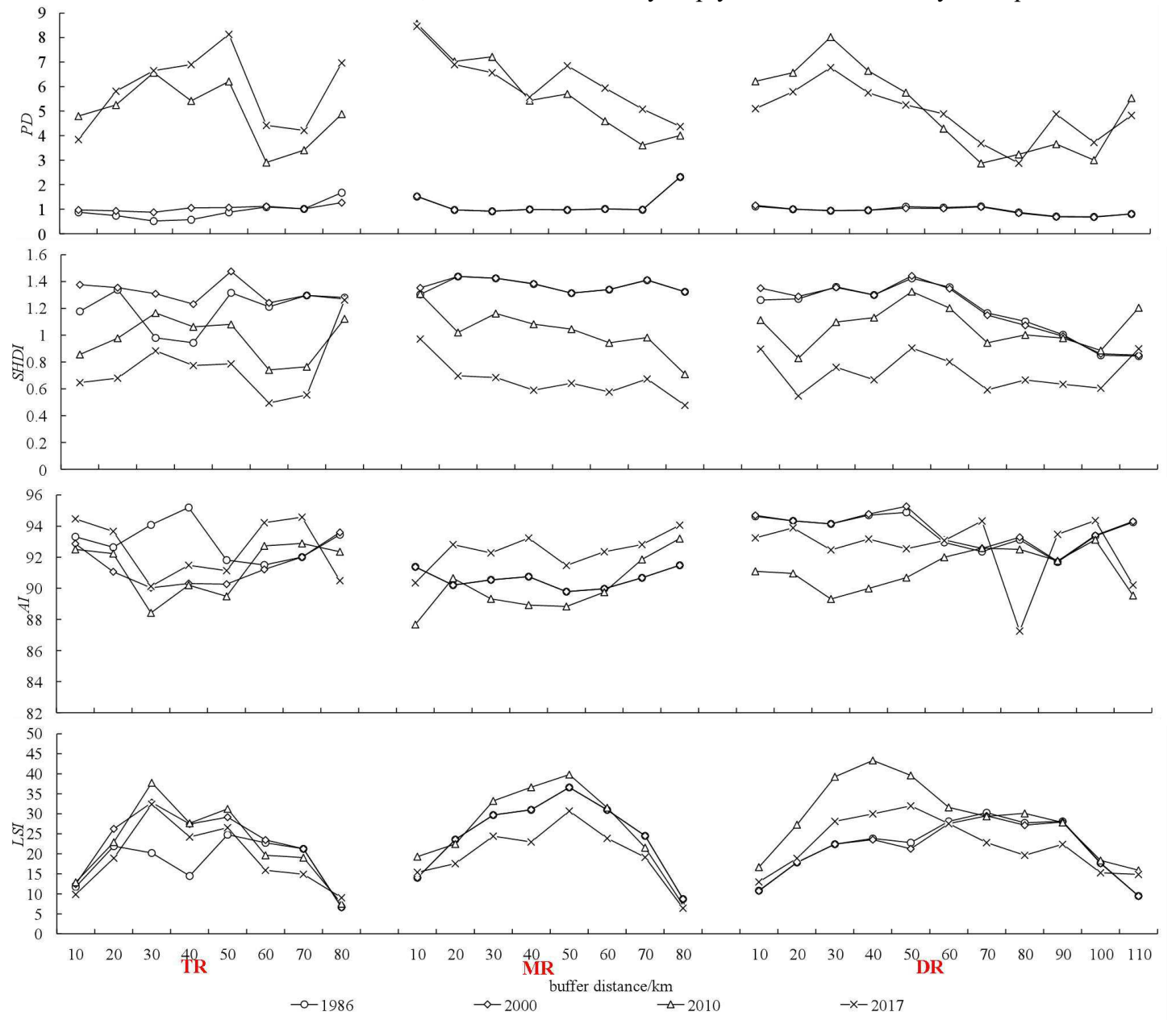

Figure 7. Changes in landscape metrics along the buffer distance of the watershed from 1986 to 2017 Characteristics of landscape indexes (PD, $A I, L S I, S H D I)$ for different land types

The different trends of the different landscape indices are shown to be under the influence of major water projects and rapid urbanization (Fig. 8). From 1986 to 2017, there was a significant increase in the $P D$ index, a wave-like downward change in the $S H D I$ and $L S I$ indices and a less pronounced change in the $A I$. These changes indicate that the fragmentation degree increased, the landscape multiplicity decreased, and the landscape shape was relatively normal with the progression of the TGP. The landscape indices of different landforms were significantly different.

Specifically, PD tended to increase with elevation and decrease with slope along with greater fragmentation of valleys and steep slopes; SHDI decreased with elevation and slope, and the ecosystem may be more homogeneous; AI decreased first and then increased with elevation and slope, respectively, with greater aggregation of elevation than slope; LSI increased first and then decreased with elevation and slope while showing "n"-shaped changes. The landscape patterns were more complex and irregular in low mountains and gentle slopes. 


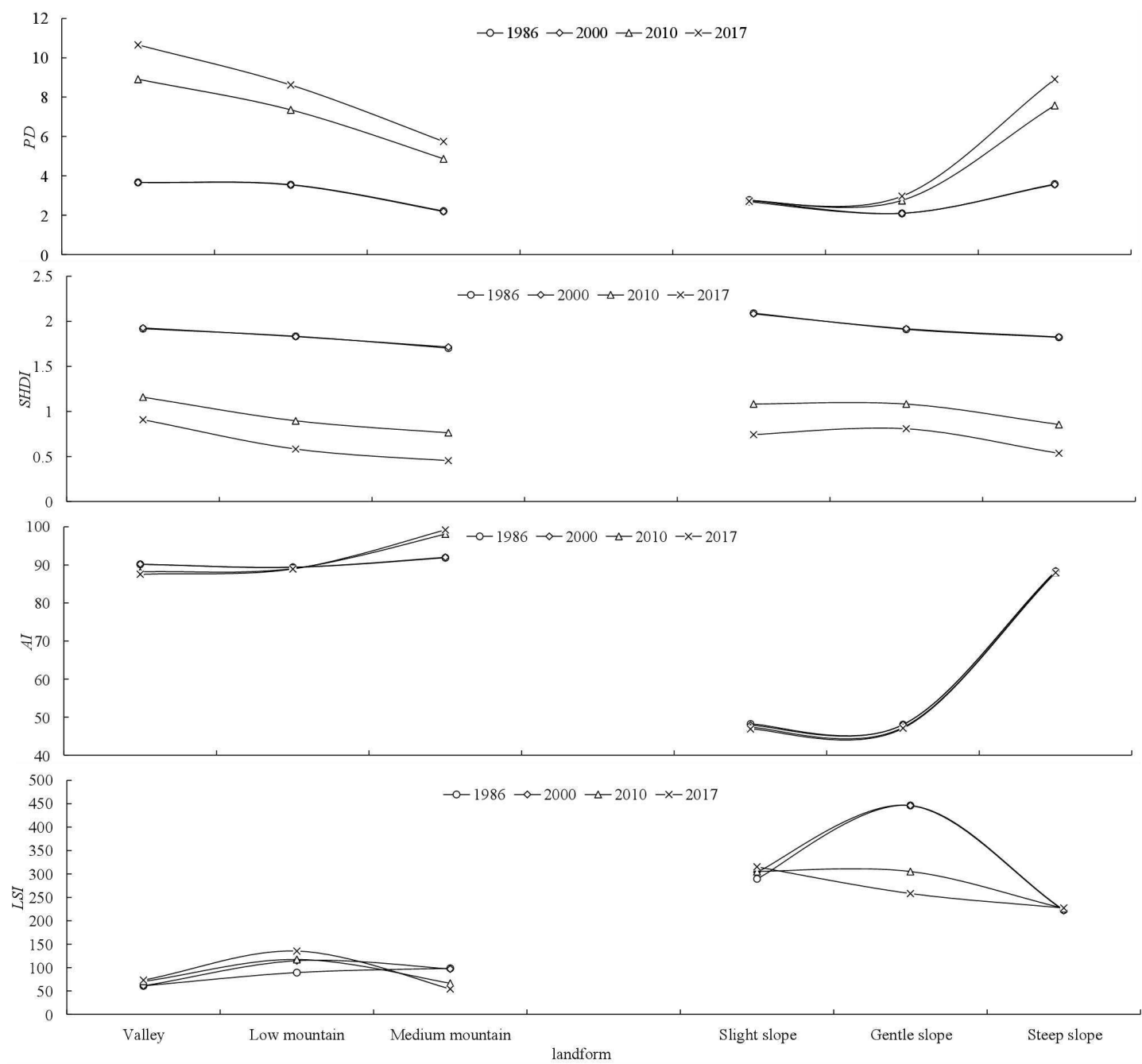

Figure 8. Changes in landscape index along landforms from 1986 to 2017 in the watershed Characteristics of changes in landscape elements and landscape indicators before and after the impounding period Changes in area and patterns of landscape elements over three time periods

From the mid-1990s to the present, the landscape of the TGRA has undergone dramatic changes due to the construction of the Three Gorges Hydropower Station (TGHS), which has attracted much attention ${ }^{33}$. Due to intense and complex human pressures, the landscape structures and ecosystem service functions in the region have experienced significant changes in the last 30 years. A large amount of land has been flooded due to the construction of hydroelectric dams and infrastructure. The relocation of immigrants and redevelopment of towns and cities have led to a dramatic decrease in the area of water in cultivated land and experienced a deceleration in growth, which is very consistent with the results indicated by previous studies ${ }^{26}$. The conversion of cropland to forest has been the dominant landscape transformation process $^{44}$, the area of cropland around the TGRA is decreasing ${ }^{26}$, and approximately $28 \%$ of farmland in China's mountainous counties is abandoned ${ }^{60}$. Landscape change is phased (Sang et al., 2019), and long-term stable landscape transitions can be used to reveal models of landscape evolution (Fig. 9).

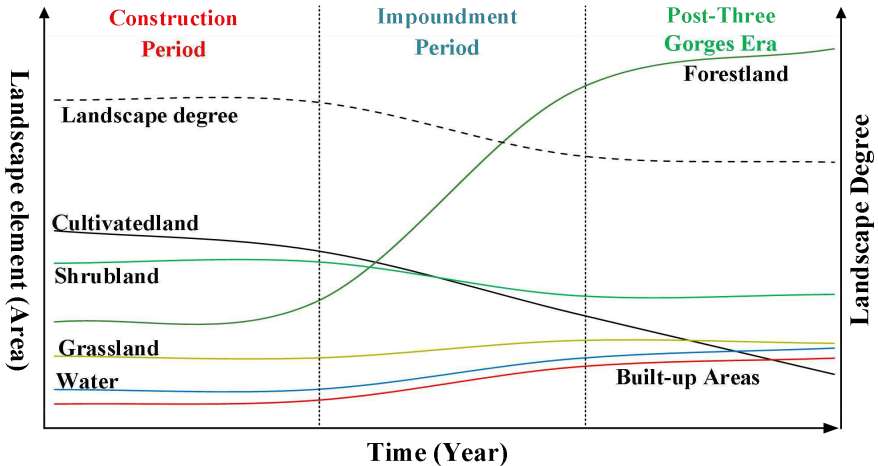

Figure 9. Change of landscape elements in the watershed 
In the first period (before 2000), there were significant interconversions between different landscape types ${ }^{34}$ with concentrated and contiguous agricultural land forming the main landscape type of the watershed. The composite index of landscape extent was higher than in the other two periods, and the trend of landscape ecological security was improving.

The direct impact on the watershed during the impoundment period from 2000 to 2010 refers to the conversion of cultivated land to water bodies ${ }^{61}$. During this period, landscape changes manifested as an increase in forestland due to the implementation of natural reserves and government forest projects. Arable lands with slopes greater than $25^{\circ}$ were best converted to forest in accordance with the arable land conversion policy ${ }^{35}$. At the same time, due to land abandonment, arable land was converted to grassland or other landscape types. The general trend of landscape change was from low-cover types to high-cover types. The overall ecological security situation has declined due to the equal emphases on development and conservation.

At the present stage (after 2010), forests form the main landscape type of the watershed. As a result of China's policies of "ecological civilization construction" and targeted poverty alleviation, farmers earn income by transforming their agricultural production methods to achieve unity of economic and ecological benefits ${ }^{62}$. The ecological security situation of the landscape shows a favorable development trend.

The landscape is affected by complex topographic variables such as elevation and slope. Given previous work, we hypothesized that the watershed contained five patterns of landscape evolution with increasing elevation, slope and buffer zone width under the influence of the TGP from 1986 to 2017 (Fig. 10). During the first period from 1986 to 2000, patterns A, B, C and E occurred in valleys with slopes less than $15^{\circ}$, all buffer zones with altitudes less than $500 \mathrm{~m}$ and slopes less than $8^{\circ}$. From 2000 to 2010, the landscape patterns of all spatial regions, especially those regions with slopes less than $15^{\circ}$ and altitudes less than $1,000 \mathrm{~m}$, were deeply influenced by human activities, and the main patterns were Mode A and Mode C. Unlike the previous phase, Mode A was distributed in the slight slope belts within the $50 \mathrm{~km}$ buffer zone due to relocation and urban renewal. From 2010 to 2017 , the landscape of the whole spatial region for Modes A, C and E was especially located in areas with slopes less than $8^{\circ}$ and elevations less than $500 \mathrm{~m}$. Mode B was distributed within a $40 \mathrm{~km}$ buffer zone with slopes less than $15^{\circ}$ and elevations greater than $1,000 \mathrm{~m}$.
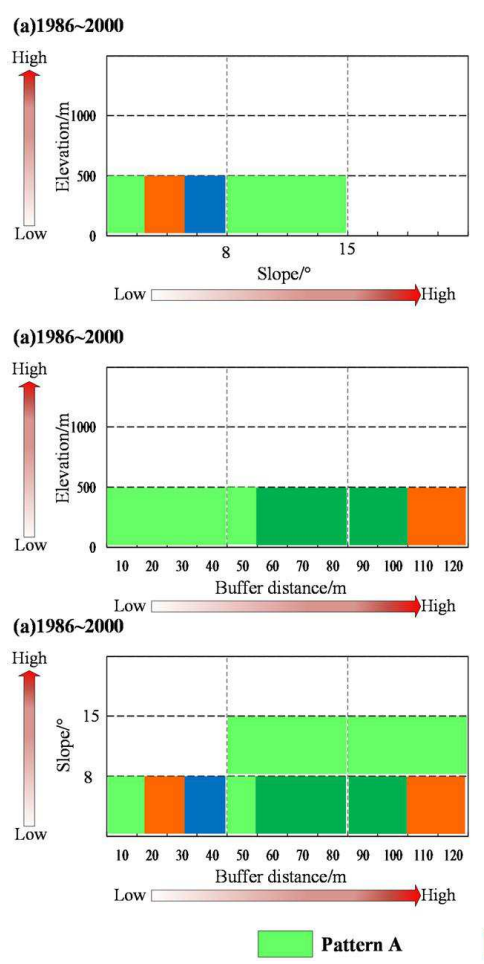
(b) 2000 -2010

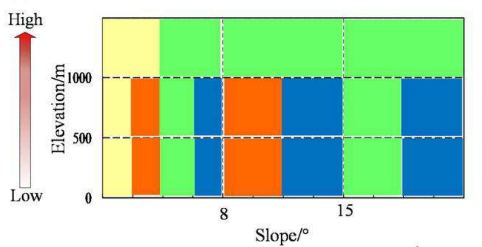

(b)2000 2010

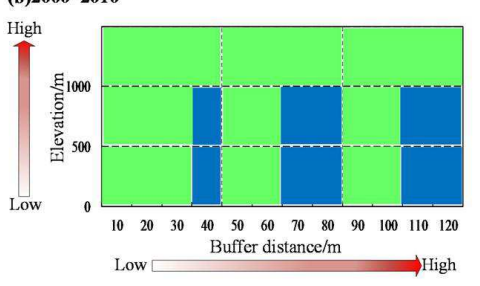

$$
\text { Low }
$$

$$
\text { (b)2000 2010 }
$$
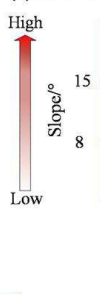

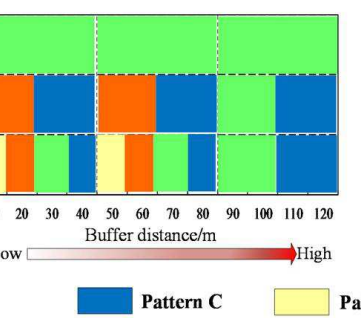
(c)2010 2017
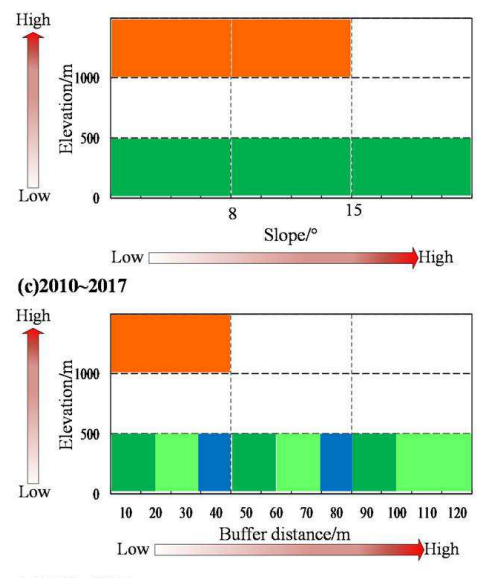

(c)2010 2017

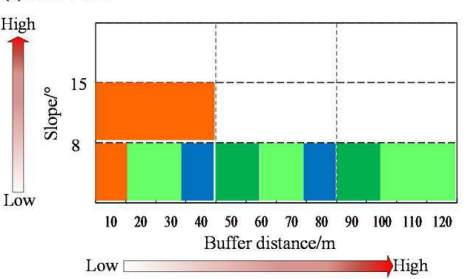

Pattern D

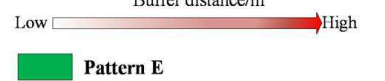

Figure 10. Landscape evolution model in a typical watershed of the TGRA

(Pattern A: conversion of other landscape types to forestland, Pattern B: conversion of other landscape types to built-up areas, Pattern C: conversion of other landscape types to water bodies, Pattern D: conversion of other landscape types to farmland, and Pattern E: conversion of other landscape types to shrubland).

\section{Changes in landscape pattern index over three time periods}

Landscape elements exhibited a distinct transformation phase before and after impoundment and are sensitive to elevation and slope $^{34}$. In this context, the changes in the landscape pattern index in this study were divided into three periods during the construction of the TGR, just as shown in Fig. 11. In the first stage (before 2000), the landscape pattern index change was not obvious, the transition of landscape categories was stable, and the landscape pattern was reflected by the reclamation of agricultural land, which increased rapidly ${ }^{31}$. In the impoundment period from 2000 to 2010, the $P D$ index exhibited a significant increase, SHDI showed a decreasing trend, and the changes in the AI and LSI indices were not obvious. For the cases of economic development and ecological protection, a landscape pattern with high heterogeneity and low diversity was present, with an increase in forest and 
water area being the most significant landscape dynamic pattern. In recent decades, (after 2010), the $P D$ index has increased significantly, the SHDI, AI and LSI indices have not changed notably, and the landscape has shifted from diversified to relatively unitary.

From 1986 to 2017, the ESI showed a trend of N, which indicated that the spatial structure of the landscape was more stable and ecological security was more reasonable due to the implementation of policies such as the return of farmland to forest and designation of red lines for ecological protection. Due to the disturbing effects of the water conservancy construction itself, it was more difficult to restore the ecosystem to its preconstruction state. As the most basic and important type of landscape, both the natural environment and human activities can significantly trigger landscape differences. The study of landscapes and their mechanistic driving factors is conducive to the optimization and improvement of policy mechanisms.

The changes in landscape elements and landscape pattern indices at different stages are consistent with the laws and needs of reservoir construction. Over time, the spatial structure of the landscape becomes more stable and ecologically safe.

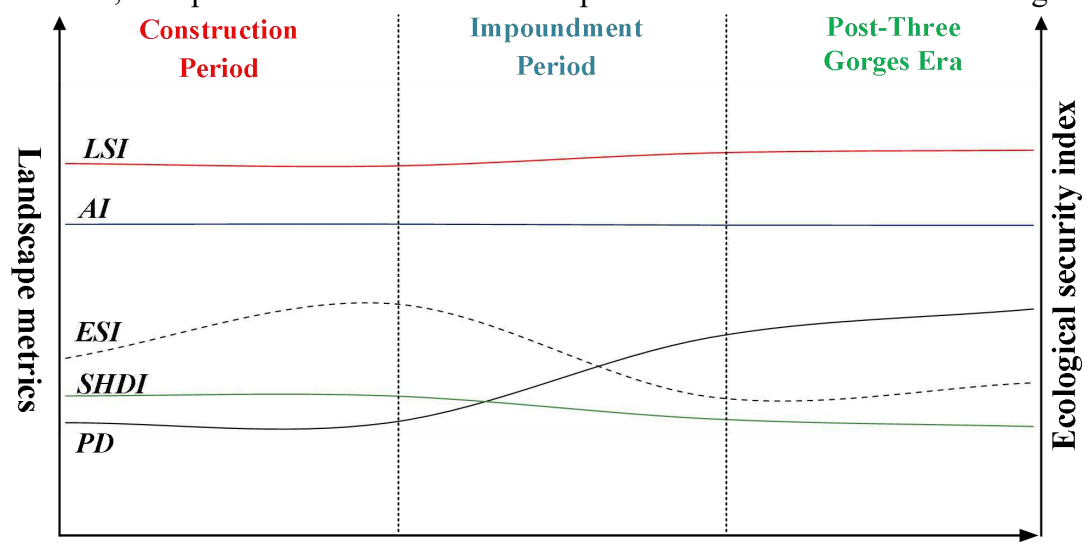

Time (Year)

\section{Conclusion}

Figure 11. Change in landscape pattern indexes in the watershed

In the context of China's "ecological civilization construction", considering the significant impact of multiple stressors of TGP construction on ecological changes, this paper analyzes the changes in the degree of landscape evolution through measures related to the analysis of land use and landscape patterns in typical watersheds of the TGRA from 1986-2017 and draws the following conclusions.

Changes in the landscape patterns of the watershed are closely related to the construction of the TGP. During the construction period from 1986-2000, landscape elements and landscape patterns did not change significantly, with arable land being the dominant landscape transformation process. From 2000 to 2010 (i.e., impoundment period), land use showed dramatic changes, with the conversion of arable land to forestland being the dominant landscape transformation process, water area changes were not significant, and landscape elements showed different trends in different regions. The results indicate that ecological conservation policies have a greater impact on land use change than reservoir impoundment. After 2010, landscape elements changed more in areas with elevations below $500 \mathrm{~m}$ and slopes below $8^{\circ}$. Changes in land use type in the watershed brought landscape changes, and landscape fragmentation and diversity showed increasing trends throughout the study period.

In this study, we employed GIS and RS tools, buffer analysis and calculations of K, P, LA, and landscape pattern indices to analyze the spatial-temporal differential characteristics of the regional landscapes that were induced by dam construction and reservoir impoundment. In view of the phase of the large water conservancy project and the particular properties of the watershed and combined with the classification of land types based on elevation and slope gradient, our study reveals the landscape ecological effects over the long term sequenced from the perspectives of speed, tendency, intensity and landscape pattern. Reservoir construction is an important human activity, and relevant studies of landscape models and patterns before/after reservoir construction can help us understand the generalizations of regional sustainable development. The landscape pattern in the riparian zone of the Three Gorges Reservoir and its response to ecological safety will be studied in the future.

\section{Methods}

\section{Elevation, slope reclassification and land types classification}

Watershed elevations were reclassified into $<500 \mathrm{~m}, 500 \mathrm{~m} \sim 1,000 \mathrm{~m}$ and $>1,000 \mathrm{~m}$ based on geomorphological classification criteria using $30 \mathrm{~m}$ spatial resolution DEM data. Slope (degrees) was extracted from the DEM. Using the slope spatial analysis tool in the ArcGIS software, we obtained a rasterized slope map of the study area. The slopes were reclassified into three grades of $<8^{\circ}$, $8^{\circ} \sim 15^{\circ}$ and $>15^{\circ 63,64}$. Based on the elevation and slope characteristics, the land types were divided into six main categories, with watershed classifications and their area percentages shown in Table 1. Watersheds are mountainous and are present where more 
than $87 \%$ of the area has a topographic slope of more than $15^{\circ}$.

Table 1. Elevations, slope reclassifications and land type classifications and their area percentages $(\%)$

\begin{tabular}{cccccc} 
Elevation Zone/m & Geomorphologic Classification & Area percentage & Slope Zone/ & Slope Classification & Area percentage \\
\hline$<500$ & Valley & 11.32 & $<8$ & Slight Slope & 3.72 \\
$500 \sim 1000$ & Low Mountain & 37.15 & $8 \sim 15$ & Gentle Slope & 8.76 \\
$>1000$ & Medium Mountain & 51.53 & $>15$ & Steep Slope & 87.52 \\
\hline
\end{tabular}

\section{Buffer Analysis}

To reflect the changes in landscape elements and landscape metrics at different distances from the mainstream of the Yangtze River, this study analyzed a buffer zone with a radius of $10 \mathrm{~km}$, which was centered on the outlets of the lower reaches (county government locations) of the three watersheds, to create a buffer zone, as shown in Fig. 12. The generated buffer zone was used to segment the landscape type status map to obtain landscape type maps of different buffer zones for each time period. The land-use change velocity index $(K)$, land-use change trend $(P)$ and land use degree index $(L A)$ were calculated by overlay analysis to analyze land use changes in different elevations and slope zones. This paper then explores the patterns of land use evolution in different buffer zones over different time periods in the watershed.
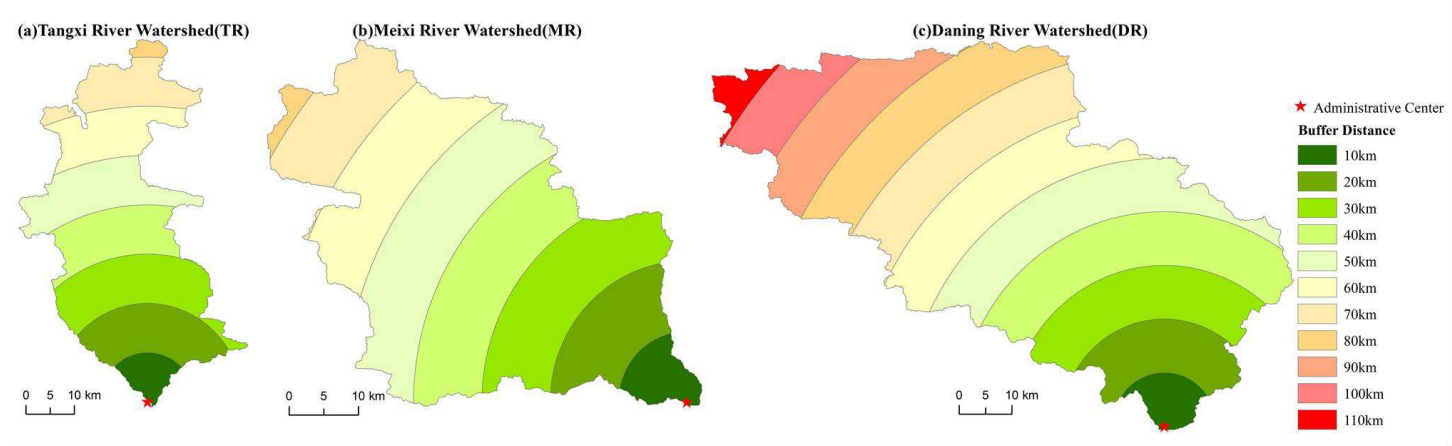

Figure 12. Setting up of watershed buffer zone

\section{Methods of landscape element change}

\section{Speed of landscape change (K)}

The single land use dynamic degree $(K)$ is used to reflect the rate of change for a certain landscape type and the differences between each type ${ }^{65,33,51}$, the mathematical expression is as follows:

$$
K=\frac{U_{t 2}-U_{t 1}}{U_{t 1}} \times \frac{1}{t_{2}-t_{1}} \times 100 \%
$$

where $U_{t 1}$ is the area of a land use type at time $t_{1}$ and $U_{t 2}$ is the area of the land use type at time $t_{2}$; if $t$ is set as one year, the value $K$ is the annual comprehensive change rate of land use in the watershed.

\section{Trends in land use change (P)}

In our study, a single land use spatial change trend model was used to reflect the changing trend of landscape types ${ }^{66}$. The basic equation is shown below:

$$
P=\frac{U_{t 2}-U_{t 1}}{\Delta U_{\text {out }}+\Delta U_{\text {in }}}
$$

where $P$ denotes the change trend index of different land use types in the river watershed; $\Delta U_{\text {out }}$ represents the sum of the areas converted from a certain land use type to other land use types during the research period; $\Delta U_{\text {in }}$ is the sum of the areas for other land use types that were converted into this type during the research period; when $-1<P \leq 0$, the scale of the land use type has decreased and is in a "weak" state and when $0<P \leq 1$, the scale of the land use type has expanded and is in a "rising" state.

\section{Calculation of land use change degree (LA)}

The synthetic land use dynamic degree is used to characterize the breadth and depth of the landscape ${ }^{67}$. According to the actual classification of land use types, they were divided into specific sets at four levels: I for unused land; II for water, bush, forestland, grassland; III for paddy field, dry land; and IV for built-up land. This division is represented by the following equation: 


$$
L A=100 \times \sum_{i=1}^{n} A_{i} \times C_{i}
$$

where $L A$ denotes the synthetic land use dynamic degree and varies from 100 to $400, A_{i}$ is the grade index of grade $i$, $C_{i}$ represents the grade $i$ land area percentage for the entire region, and $n$ is the number of grades, e.g., $i=1,2,3,4$.

\section{Selection and calculation of four landscape metrics}

Here, four landscape indices, namely, patch density $(P D)$, Shannon's diversity index (SHDI), aggregation index ( $A I)$, and landscape shape index $(L S I)$ were selected and measured by using FRAGSTATS 4.2 software $^{68}$ to characterize the general landscape, and the information for the selected landscape is shown in Table 2.

Table 2. Selected landscape metrics of the watershed

\begin{tabular}{|c|c|c|c|c|c|}
\hline Item & Abbr. & & Mathematical expression & Data range & Parameter meaning \\
\hline Patch density & $P D$ & & $P D=N / A$ & $P D>0$ & $A$ is the total landscape area \\
\hline $\begin{array}{l}\text { Shannon's diversity } \\
\text { index }\end{array}$ & SHDI & & $S H D I=-\sum_{i=1}^{n} P_{i} \ln P_{i}$ & $S H D I \geq 0$, without limit & $\begin{array}{c}P_{i} \text { is the area proportion of } \\
\text { landscape } i\end{array}$ \\
\hline Aggregation index & $A I$ & $A I=$ & $=\left[\sum_{i=1}^{m}\left(\frac{g_{i j}}{\max \longrightarrow g_{i j}}\right)\right](100)$ & $0 \leq A I \leq 100$ & $\begin{array}{c}g_{i j} \text { is the number of similar adjacent } \\
\text { patches of plaque type }\end{array}$ \\
\hline Landscape shape index & $L S I$ & & $L S I=\frac{0.25 E}{\sqrt{A}}$ & $L S I \geq 0$, without limit & $\begin{array}{l}E \text { is the total length of all patch } \\
\text { boundaries in the landscape }\end{array}$ \\
\hline
\end{tabular}

\section{Establishment of a landscape ecological security index system}

The landscape ecological security index reflects the impact of natural and human pressures on ecological security from the landscape perspective. In this study, however, the landscape disturbance index $(L D I)$ and landscape vulnerability index $(L V I)$ were calculated as causal indices to measure landscape ecology based on representative landscape indices ${ }^{69,70}$. In general, the greater the level of disturbance and vulnerability, the lower the level of ecological safety. The landscape disturbance index $(L D I)$ is generally reflected by the combined state of patch density (PD), fractal dimension (FRAC), and Shannon's diversity index (SHDI). The LDIi is calculated by the following formula.

$$
L D I_{i}=\alpha P D+\beta S H D I+\gamma F R A C
$$

where the index weights are $\alpha, \beta$, and $\gamma$, respectively, and they are given values of $0.5,0.3$, and 0.2 .

In general, landscape ecological security is related to landscape vulnerability, and the landscape vulnerability index ( $L V I)$ mainly reflects the degree of variation of each landscape type in the watershed after being disturbed. In turn, there are differences in the degree of disturbance resistance and sensitivity of different landscape types. We assigned vulnerability values to different landscape types: built-up areas 1, forestland and shrubland 2, grassland 3, cultivated land (dryland and paddy field) 4, and water area 4.

Thus, it is possible to construct a landscape ecological security index (LESI) based on normalized landscape metrics, which are area-weighted and summed by $L D I$ and $L V I$ combined. $L E S I$ is represented by the following equation.

$$
L E S I_{k}=\sum_{i=1}^{n} \frac{A_{k i}}{A_{k}} \times\left(1-10 \times L D I_{i} \times L V I_{i}\right)
$$

where $L E S I_{k}$ is the landscape ecological security index of evaluation unit $k, n$ is the number of evaluation units, $A_{k i}$ is the area of landscape type $i$ in evaluation unit $k$, and $A_{k}$ is the total area of evaluation unit $k$.

\section{References}

1. ICOLD (International Commission On Large Dams). World Register of Dams. Preprint at https://www.icold-cigb.org/GB/world_register/world_register_of dams.asp (2020).

2. Lehner, B., et al. High resolution mapping of the world's reservoirs and dams for sustainable river flow management. Front Ecol Environ. 9(9),494-502, DOI: https://doi.org/10.1890/100125 (2013).

3. Moussa, A., Soliman, M.\& Aziz, M. Environmental evaluation for High Aswan Dam since its construction until present. In: 
Sixth International Water Technology Conference, IWTC, Alexandria, Egypt (2001).

4. Strand, H., et al. Sourcebook on remote sensing and biodiversity indicators. NASA-NGO Biodiversity Working Group and UNEP-WCMC (2007).

5. Grumbine, R.E. \& Pandit, M.K. Threats from India's Himalaya dams. Science. 339(6115),36-37, DOI: https://doi.org/10.1126/science.1227211 (2013).

6. Chen, C., Ma, M., Wu, S., Jia, J. \& Wang, Y. Complex effects of landscape, habitat and reservoir operation on riparian vegetation across multiple scales in a human-dominated landscape. Ecol Indic. 94,482-490, DOI: https://doi.org/10.1016/j.ecolind.2018.04.040 (2018).

7. Milliman, J.D. \& Meade, R.H. World-wide delivery of river sediment to the oceans. J Geol. 91,1-21 (1983).

8. Tonkin, J.D., et al. Flow regime alternation degrades ecological networks in riparian ecosystems. Nat Ecol Evol. 2,86-93, DOI: https://doi.org/10.1038/s41559-017-0379-0 (2018).

9. Nillson, C., Reidy, C.A., Dynesius, M. \& Revenga, C. Fragmentation and flow regulation of the world's large river systems. Science. 308,405-408 (2005).

10. Mitsch, W., et al. Optimizing ecosystem services in China. Science. 322(5901),528 (2008).

11. Stone, R. Three Gorges Dam: into the unknown. Science. 333,817 (2008).

12. Fu, B.J., et al. Three Gorges Project: efforts and challenges for the environment. Prog Phys Geog. 34(6),741-754, DOI: http://dx.doi.org/10.1177/0309133310370286 (2010).

13. Xu, X.B., et al. Unravelling the effects of large-scale ecological programs on ecological rehabilitation of China's Three Gorges Dam. J Clean Prod. 256, DOI: https://doi.org/10.1016/j.jclepro.2020.120446 (2020).

14. Yaeger, M.A., Massey, J.H., Reba, M.L. \& Adviento-Borbe, M.A.A. Trends in the construction of on-farm irrigation reservoirs in response to aquifer decline in eastern Arkansas: Implications for conjunctive water resource management. Agr Water Manage. 208,373-383, DOI: https://doi.org/10.1016/j.agwat.2018.06.040 (2018)

15. Bai, J., et al. Soil organic carbon contents of two natural inland saline-alkalined wetlands in northeastern china. $J$ Soil Water Conserv. 62(6),447-452 (2007).

16. Chen, L.G., Qian, X. \& Shi, Y. Critical area identification of potential soil loss in a typical watershed of the Three Gorges Reservoir Region. Water Resour Manag. 25(13),3445-3463,DOI: https://doi.org/10.1007/s11269-011-9864-4 (2011).

17. Xiao, Q., Xiao, Y. \& Tan, H. Changes to soil conservation in the Three Gorges Reaervoir Area between 1982 to 2015 . Environ Monit Assess. 192,44,DOI: https://doi.org/10.1007/s10661-019-7983-1 (2020).

18. Zhao, Q.H., et al. Landscape change and hydrologic alteration associated with dam construction. Int J Appl Earth Obs. 16(1),17-26,DOI: https://doi.org/10.1016/j.jag.2011.11.009 (2012).

19. Zhao, C.L., et al. Ecological Security Patterns Assessment of Liao River Basin. Sustainability. 10,2401,DOI: https://doi.org/10.3390/su10072401 (2018).

20. Gustafson, E.J., Roberts, L.J. \& Leefers, L.A. Linking linear programming and spatial simulation models to predict landscape effects of forest management alternatives. $J$ Environ Manage. 81(4),339-350,DOI: https://doi.org/10.1016/j.jenvman.2005.11.009 (2006).

21. Restrepo, A.M.C., et al. Land cover change during a period of extensive landscape restoration in Ningxia Hui Autonomous Region, China. Sci Total Environ. 598,669-679, DOI: https://doi.org/10.1016/j.scitotenv.2017.04.124 (2017).

22. Gong, W.F., et al. Effect of terrain on landscape patterns and ecological effects by a gradient-based RS and GIS analysis. $J$ For Res. 28(5),1061-1072, DOI: https://doi.org/10.1007/s11676-017-0385-8 (2017).

23. Birhane, E., et al. Land use land cover changes along topographic gradients in Hugumburda national forest priority area, Northern Ethiopia. Remote Sensing Applications: Society and Environment, 13,61-68, DOI: https://doi.org/10.1016/j.rsase.2018.10.017 (2019).

24. Tian, P., et al. Research on land use changes and ecological risk assessment in Yangjiang River Basin in Zhejiang Province, China. Sustainability. 11(10),2817, DOI: https://doi.org/10.3390/su11102817 (2019).

25. Xiong, M., Xu, Q.X. \& Yuan, J. Analysis of multi-factors affecting sediment load in the Three Gorges Reservoir. Quatern Int.208, 76-84, DOI: https://doi.org/10.1016/j.quaint.2009.01.010 (2009).

26. Feng, L. \& Xu, J.Y. Farmers'willingness to participate in the next-stage Grain-for-Green project in the Three Gorges Reservoir Area, China. Environ Manage. 56,505-518, DOI: https://doi.org/10.1007/s00267-015-0505-1 (2015).

27. Cao, S., et al. Ecosystem water imbalances created during ecological restoration by afforestation in China, and lessons for other 
developing countries. J Environ Manage. 183,843-849, DOI: https://doi.org/10.1016/j.jenvman.2016.07.096 (2016).

28. Xu, X.B., Tan, Y. \& Yang, G.S. Environmental impact assessments of the Three Gorges Project in China: issues and interventions. Earth-sci Rev. 124,115-125, DOI: https://doi.org/10.1016/j.earscirev.2013.05.007 (2013).

29. Zhong, S.Q., et al. Mechanized and optimized configuration pattern of crop-mulberry systems for controlling agricultural non-point source pollution on sloping farmland in the Three Gorges Reservoir Area, China. Int J Env Res Pub He. 17,3599, DOI: https://doi.org/10.3390/ijerph17103599 (2020).

30. Qi, S.W., Yue, Z.Q., Liu, C.L. \& Zhou, Y.D. Significance of outward dipping strata in argillaceous limestones in the area of the Three Gorges reservoir, China. Bull Eng Geol Environ. 68,195-200, DOI: https://doi.org/10.1007/s10064-009-0206-1 (2009).

31. Zhang, Q., et al. The spatial granularity effect, changing landscape patterns, and suitable landscape metrics in the Three Gorges Reservoir Area, 1995-2015. Ecol Indic. 114, DOI: https://doi.org/10.1016/j.ecolind.2020.106259 (2020).

32. Shen, Z.Y., et al. A comparison of WEPP and SWAT for modeling soil erosion of the Zhangjiachong Watershed in the Three Gorges Reservoir Area. Agr Water Manage. 96,1435-1442, DOI: https://doi.org/10.1016/j.agwat.2009.04.017 (2009).

33. Zhang, J.X., Liu, Z.J. \& Sun, X.X. Changing landscape in the Three Gorges Reservoir Area of Yangtze River from 1977 to 2005: Land use/land cover, vegetation cover changes estimated using multi-source satellite data. Int J Appl Earth Obs. (11),403-412, DOI: https://doi.org/10.1016/j.jag.2009.07.004 (2009).

34. Huang, C.B., et al. Land use/cover change in the Three Gorges Reservoir area, China: Reconciling the land use conflicts between development and protection. Catena. 175,388-399, DOI: https://doi.org/10.1016/j.catena.2019.01.002 (2019).

35. Wang, W. \& Pu, Y. Analysis of landscape patterns and the trend of forest resources in the Three Gorges Reservoir area. Journal of Geoscience and Environment Protection. 6,181-192, DOI: https://doi.org/10.4236/gep.2018.65015 (2018).

36. Li, Z., Wang, R., Zhou, Z. \& Luo, X. Three Gorges Project's impact on the water resource and environment of Yangtze River. $J$ Applied Sci. 13(17),3394-3399, DOI: https://doi.org/10.3923/jas.2013.3394.3399 (2013).

37. He, J.H., Huang, J.L. \& Li, C. The evaluation for the impact of land use change on habitat quality: A joint contribution of cellular automata scenario simulation and habitat quality assessment model. Ecol Model. 366,58-67, DOI: https://doi.org/10.1016/j.ecolmodel.2017.10.001 (2017).

38. Kelly, M., Tuxen, K,A. \& Stralberg, D. Mapping changes to vegetation pattern in a restoring wetland: Finding pattern metrics that are consistent across spatial scale and time. Ecol Indic. 11(2),263-273, DOI: https://doi.org/10.1016/j.ecolind.2010.05.003 (2011).

39. Haycock, N.E. \& Muscutt, A.D. Landscape management strategies for the control of diffuse pollution. Landscape Urban Plan. 31(1/3),313-321, DOI: https://doi.org/10.1016/0169-2046(94)01056-E (1995).

40. Vimal, R., et al. Exploring spatial patterns of vulnerability for diverse biodiversity descriptors in regional conservation planning. J Environ Manage. 95(1),9-16, DOI: https://doi.org/10.1016/j.jenvman.2011.09.018 (2012).

41. Saura, S. Effects of remote sensor spatial resolution and data aggregation on selected fragmentation indices. Landscape Ecol. 19(2),197-209, DOI: https://doi.org/10.1023/B:LAND.0000021724.60785.65 (2004).

42. Kerenyi, A. \& Szabo, G. Human impact on topography and landscape pattern in the Upper Tisza region, NE-Hungary. Geogr. Fis Din Quat. 30(2),193-196, DOI: https://doi.org/10.1144/GSL.SP.2007.270.01.17 (2007).

43. Zhang, Y.X., et al. Changes in cultivated land patterns and driving forces in the Three Gorges Reservoir area, China, from 1992 to 2015. J Mt Sci. 17(1),203-215, DOI: https://doi.org/10.1007/s11629-019-5375-1 (2020).

44. Teng, M.J., et al. Impacts of forest restoration on soil erosion in the Three Gorges Reservoir area, China. Sci Total Environ. 697,134164, DOI: https://doi.org/10.1016/j.scitotenv.2019.134164 (2019).

45. Galicia, L., et al. Land use/cover, landforms and fragmentation patterns in a tropical dry forest iin the southern Pacific region of Mexico. Singapore J Trop Geo. 29(2),137-154, DOI: https://doi.org/10.1111/j.1467-9493.2008.00326.x (2008).

46. He, L.H., King, L. \& Tong, J. On the land use in the Three Gorges Reservoir area. J Geogr Sci. 13(4),416-422, DOI: https://doi.org/10.1007/BF02837879 (2003).

47. Gao, J.M., et al. Bioavailability of organic phosphorus in the water level fluctuation zone soil and the effects of ultraviolet irradiation on it in the Three Gorges Reservoir, China. Sci. Total Environ. 738,139912, DOI: https://doi.org/10.1016/j.scitotenv.2020.139912 (2020).

48. Xie, Y.H., et al. The impact of Three Gorges Dam on the downstream eco-hydrological environment and vegetation distribution of East Dongting Lake. Ecohydrology. 8(4),738-746, DOI: https://doi.org/10.1002/eco.1543 (2015).

49. Cai, H.Y., et al. Quantifying the impact of the Three Gorges Dam on the thermal dynamics of the Yangtze River. Environ Res 
Lett. 13,(0540165), DOI: https://doi.org/10.1088/1748-9326/aab9e0 (2018).

50. Tang, Q., et al. Flow regulation manipulates contemporary seasonal sedimentary dynamics in the reservoir fluctuation zone of the Three Gorges Reservoir, China. Sci Total Environ. 548,410-420,DOI:https://doi.org/10.1016/j.scitotenv.2015.12.158 (2016).

51. Shen, Z.Y., et al. Assessment of nitrogen and phosphorus loads and casual factors from different land use and soil types in the Three Gorges Reservoir Area. Sci Total Environ. 454-455,383-392,DOI: https://doi.org/10.1016/j.scitotenv.2013.03.036 (2013).

52. Zhu, K.W., et al. Vegetation of the water-level fluctuation zone in the Three Gorges Reservoir at the initial impoundment stage. Glob Ecol Conserv. 21,e00866, DOI: https://doi.org/10.1016/j.gecco.2019.e00866 (2020).

53. Chen, C.D., et al. Restoration design for Three Gorges Reservoir shorelands, combining Chinese traditional agro-ecological knowledge with landscape ecological analysis. Ecol Eng.71,584-597,DOI:https://doi.org/10.1016/j.ecoleng.2014.07.008 (2014).

54. Bao, Y., Gao, P. \& He, X. The water-level fluctuation zone of Three Gorges Reservoir-a unique geomorphological unit. Earth Rev. 150,14-24, DOI: https://doi.org/10.1016/j.earscirev.2015.07.005 (2015).

55. Li, Y., et al. Homogeneous selection dominates the microbial community assembly in the sediment of the Three Gorges Reservoir. Sci Total Environ. 690,50-60, DOI: https://doi.org/10.1016/j.scitotenv.2019.07.014 (2019).

56. Wang, L.J., et al. Role of reservoir construction in regional land use change in Pengxi River basin upstream of the Three Gorges Reservoir in China. Environ Earth Sci. 75,1048, DOI: https://doi.org/10.1007/s12665-016-5758-3 (2016).

57. Zhong, H.P., et al. Analysis of stage response of land use in Three Gorges Reservoir area: taking Hubei section of the reservoir area as an example. Journal of Central Normal University (Nat. Sci.). 53(4),582-593, DOI: https://doi.org/10.19603/j.cnki.1000-1190.2019.04.019 (2019).

58. Otukei, J.R. \& Blaschke, T. Land cover change assessment using decision trees, support vector machines and maximum likelihood classification algorithms. Int J Appl Earth Obs Geoinf. 12S,S27-S31,DOI: https://doi.org/10.1016/j.jag.2009.11.002 (2010).

59. Li, R.K., Li, Y.B., Wen, W. \& Zhou, Y.L. Comparative study on spatial difference of elevation and slope in soil erosion evolution in typical watershed. Journal of Soil and Water Conservation. 31(5),99-107, DOI: https://doi.org/10.13870/j.cnki.stbcxb.2017.05.016 (2017).

60. Li, S.F., et al. An estimation of the extent of cropland abandonment in mountainous regions of China. Land Degrad Dev. 29(5),1327-1342, DOI: https://doi.org/10.1002/ldr.2924 (2018c).

61. Strehmel, A., Schmalz, B. \& Fohrer, N. Evaluation of land use, land management and soil conservation strategies to reduce non-point source pollution loads in the Three Gorges Region, China. Environ Manage, 58,906-921, DOI: https://doi.org/10.1007/s00267-016-0758-3 (2016).

62. Liang, X.Y., et al. Traditional agroecosystem transition in mountainous area of Three Gorges Reservoir Area. J Geogr Sci. 30(2),281-296, DOI: https://doi.org/10.1007/s11442-020-1728-5 (2020).

63. Li, R.K., et al. Study on the temporal and spatial variation of soil erosion intensity in typical watersheds of the Three Gorges Reservoir Area from 1988 to 2015: A case based on the Daning and Meixi River Watershed. Acta Ecological Sinica. 38(17),6243-7257, DOI: https://doi.org/10.5846/stxb201706071040 (2018).

64. Birhanu, L., Hailu, B,T., Bekele, T. \& Demissew. Land use/land cover change along elevation and slope gradient in highlands of Ethiopia. Remote Sensing Applications: Society and Environment. 16,100260, (2019).

65. Xiao, J.Y.,et al. Evaluating urban expansion and land use change in Shijiazhuang, China, by using GIS and remote sensing. Landscape Urban Plan. 75,69-80, DOI: https://doi.org/10.1016/j.landurbplan.2004.12.005 (2006).

66. Ye, Q.H., et al. Geospatial-temporal analysis of land-use changes in the Yellow River Delta during the last 40 years. Sci China Ser D. 47,1008-1024, DOI: https://doi.org/10.1360/03yd0151 (2004).

67. Liu, J.Y. The land use in Xizang Autonomous Region. Science Press. Beijing (1992).

68. McGarigal, K., Cushman, S.A. \& Ene, E. FRAGSTATS v4: spatial pattern analysis program for categorical and continuous maps. Computer software program produced by the authors at the University of Massachusetts, Amherst. Preprint at http://www.umass.edu/landeco/research/fragstats/fragstats.html (2012).

69. Liu, X.L., Yang, Z.P., Di, F. \& Chen, X.G. Evaluation on tourism ecological security in nature heritage sites-case of Kanas nature reserve of Xinjiang, China. Chin Geogra Sci. 19(3),265-273, DOI: https://doi.org/10.1007/s11769-009-0265-z (2009).

70. Zhang, R.S., et al. Landscape ecological security response to land use change in the tidal flat reclamation zone, China. Environ Monit Assess. 188(1), DOI: https://doi.org/10.1007/s10661-015-4999-z (2016).

\section{Acknowledgements}


This research is funded by the National Natural Science Foundation of China (No. 41261045, No. 41661020) and the Chongqing Research Program of Basic Research and Frontier Technology (No. cstc2015jcyjBX0128, No. cstc2018jcyjAX0539). The authors would like to thank the anonymous reviewers for their valuable comments.

\section{Author contributions statement}

R.L. conceived the methodology, data process and analyzed the results, Y.L. conducted the introduction and funding acquisition, B.L. analysed the results and conclusions. All authors reviewed the manuscript.

\section{Competing interests}

The authors declare no competing interests. 
$1983-2000$

Construction Period

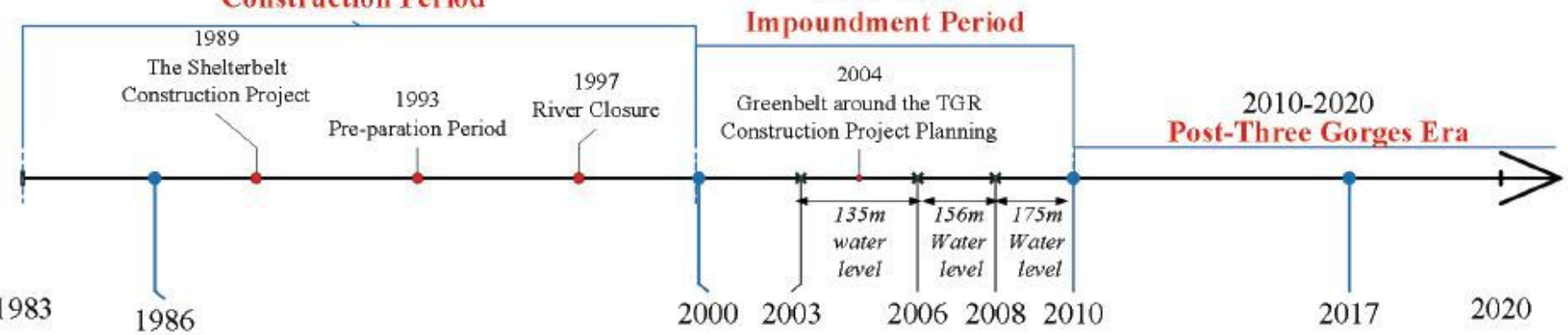

\section{Figure 1}

Construction timeline of the TGP.
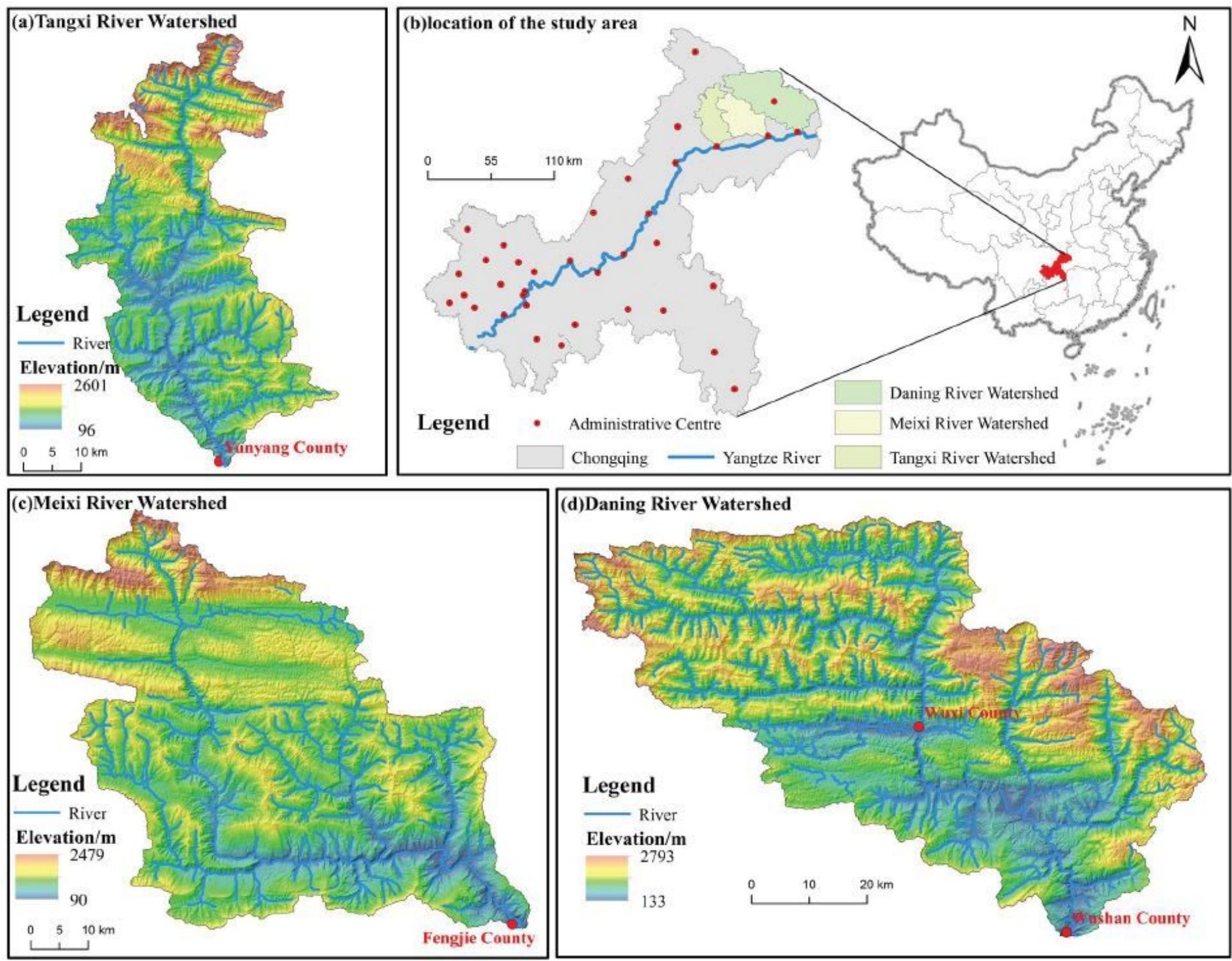
Location and topography of the study area in the Three Gorges Reservoir Area Note: The designations employed and the presentation of the material on this map do not imply the expression of any opinion whatsoever on the part of Research Square concerning the legal status of any country, territory, city or area or of its authorities, or concerning the delimitation of its frontiers or boundaries. This map has been provided by the authors.
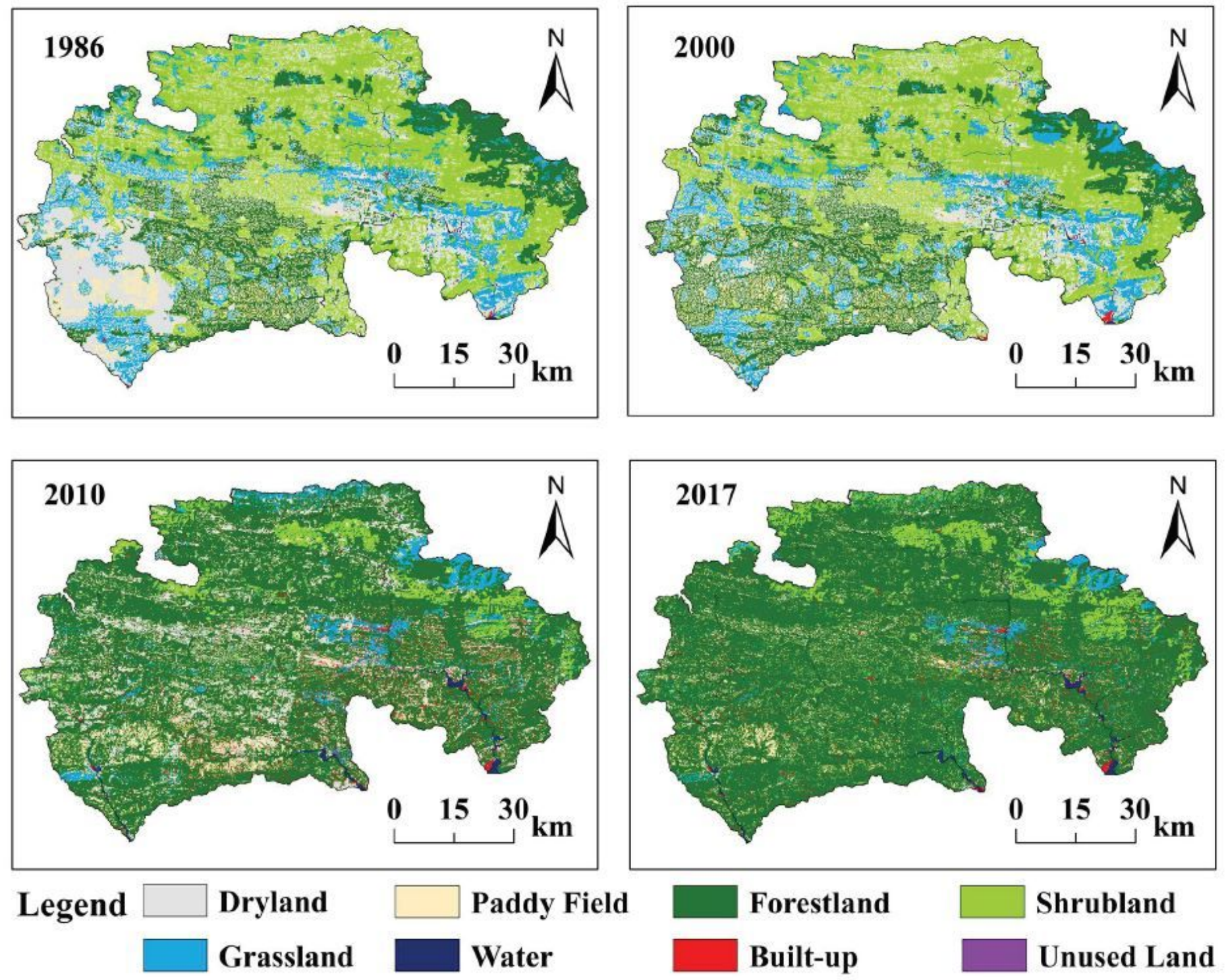

Figure 3

Spatial division of landscape type in watershed from 1986 to 2017 Note: The designations employed and the presentation of the material on this map do not imply the expression of any opinion whatsoever on the part of Research Square concerning the legal status of any country, territory, city or area or of its authorities, or concerning the delimitation of its frontiers or boundaries. This map has been provided by the authors. 

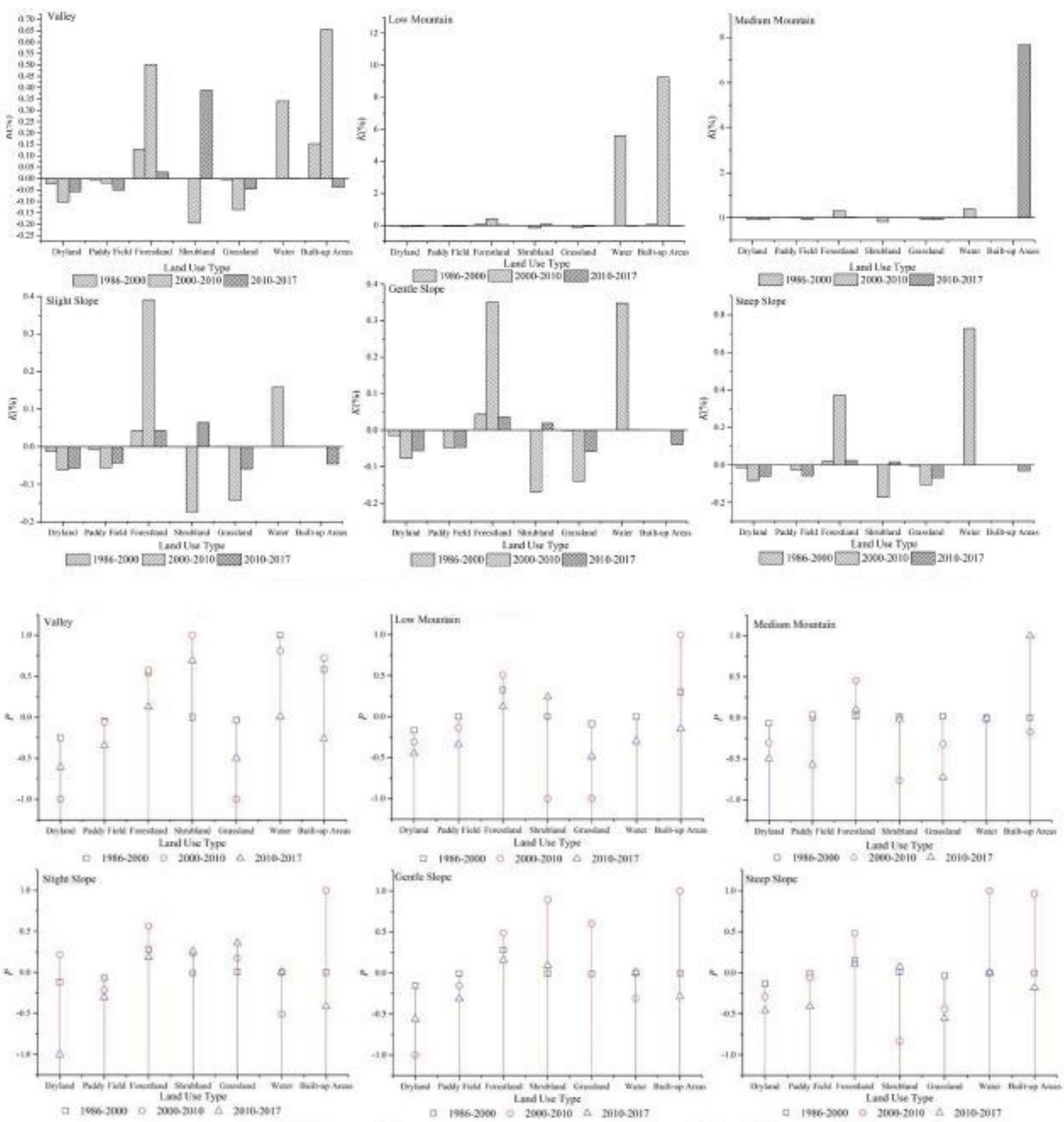

Figure 4

Figure 4a. Speed of different landscape types for different land types of the watersheds Figure 4b. Trend of different landscape types for different landforms of the watershed 


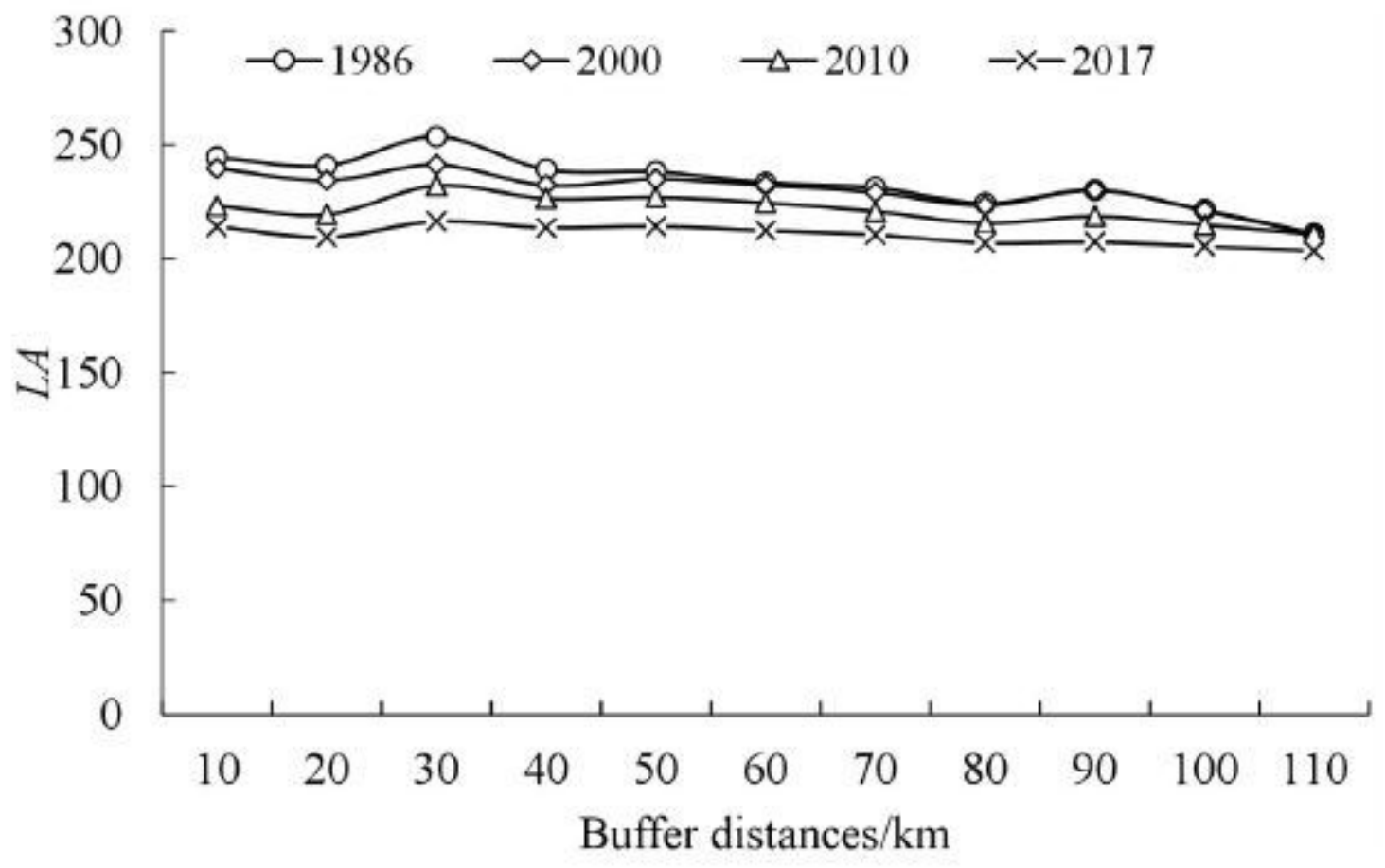

Figure 5

Comprehensive landscape degree index in buffer zone of the watershed 

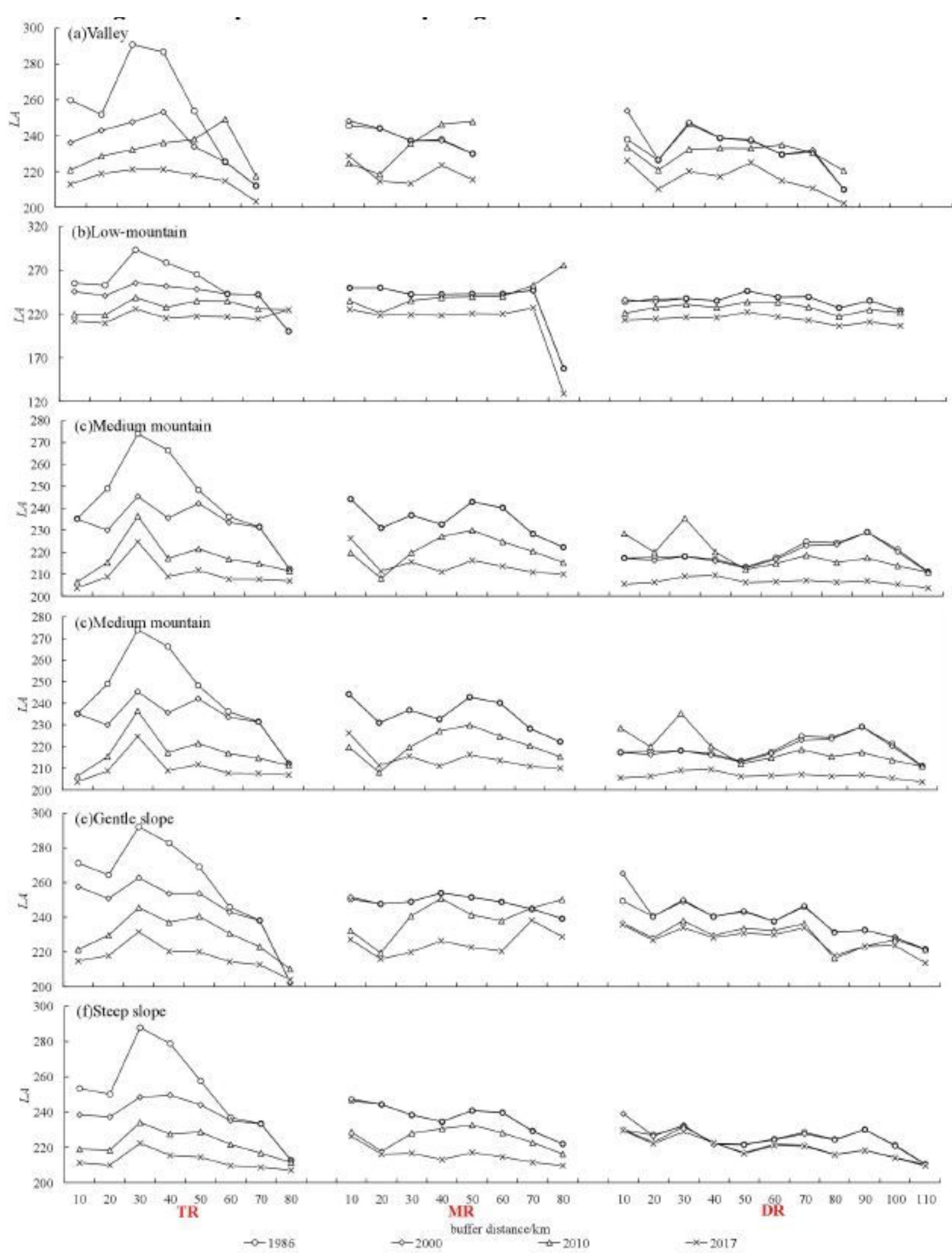

\section{Figure 6}

Comparison of LA in different buffer zones of watersheds from 1986 to 2017 


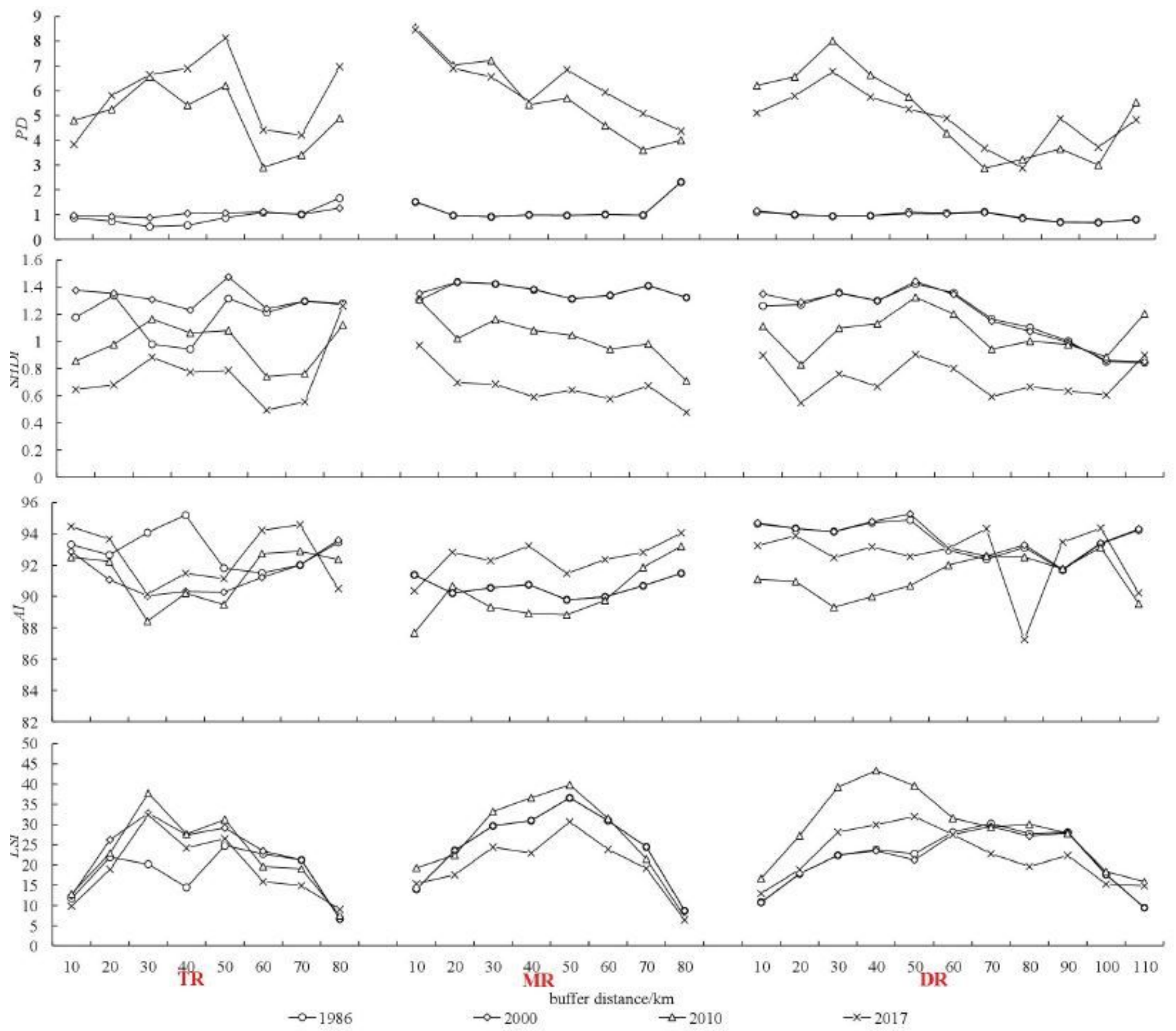

Figure 7

Changes in landscape metrics along the buffer distance of the watershed from 1986 to 2017 


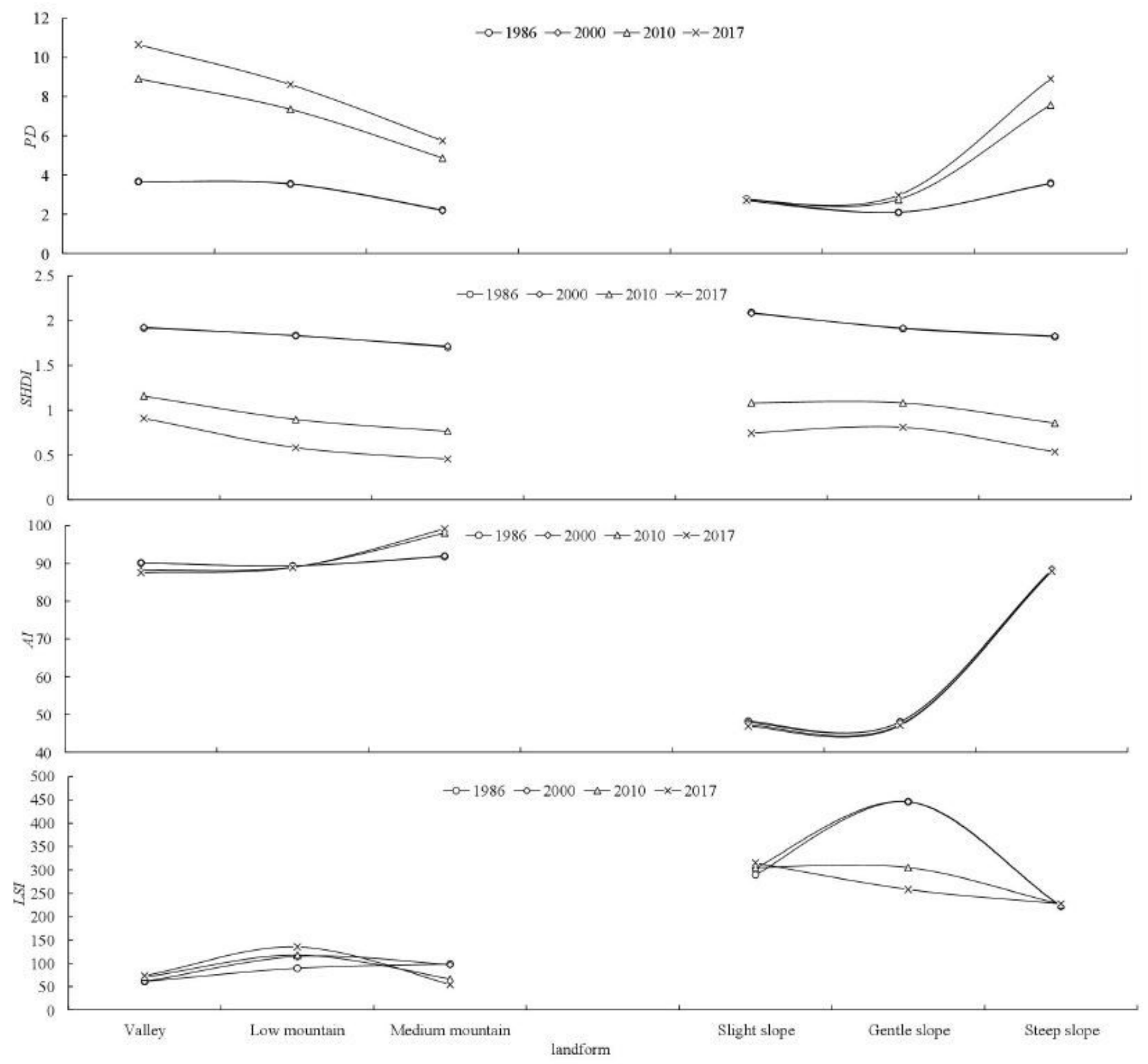

Figure 8

Changes in landscape index along landforms from 1986 to 2017 in the watershed 


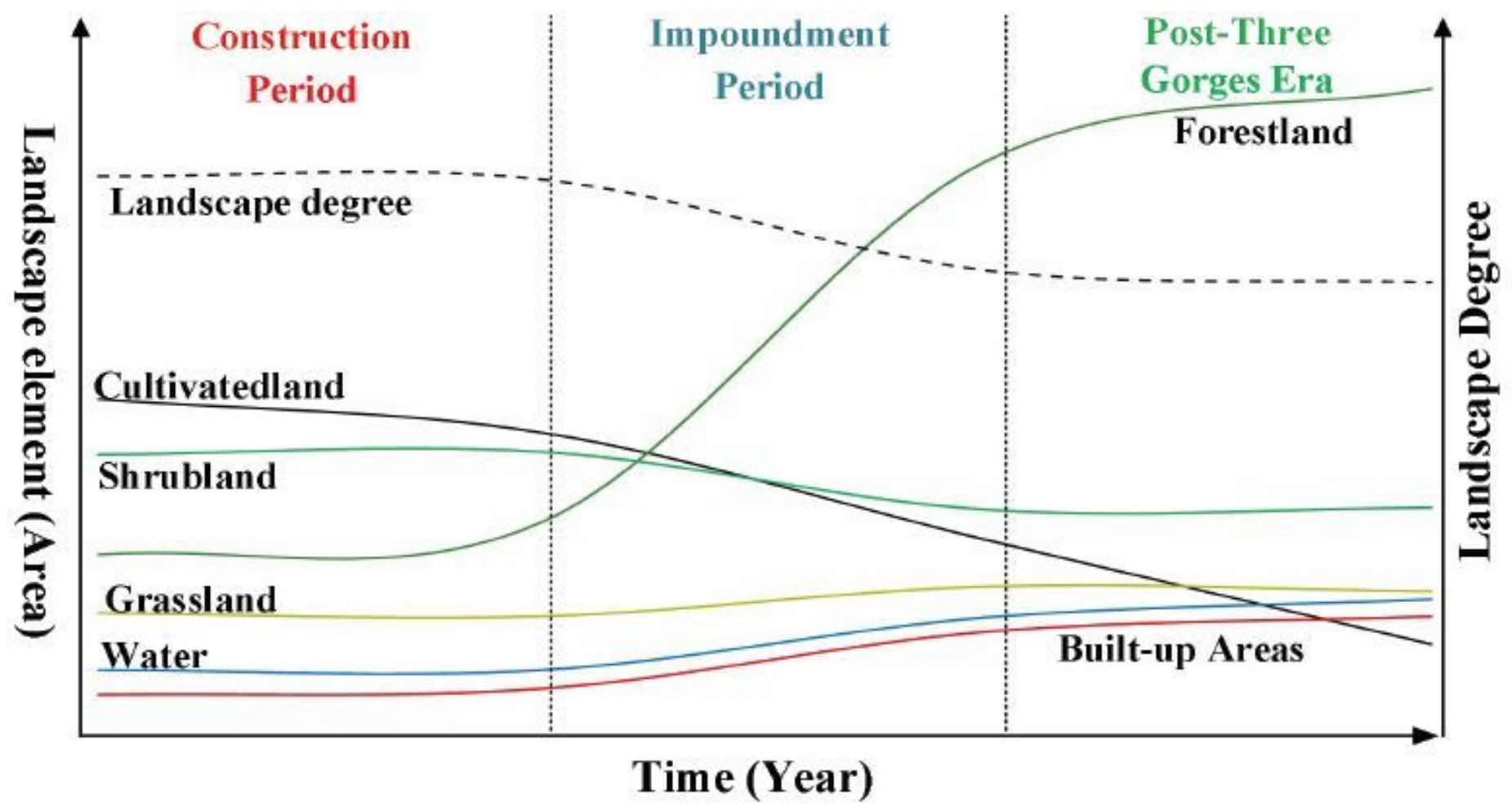

Figure 9

Change of landscape elements in the watershed

(a)1986 2000

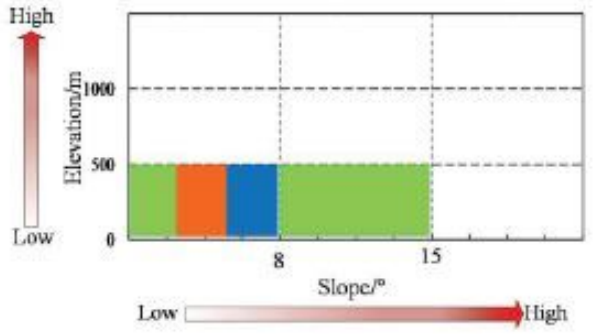

(a)1986-2000

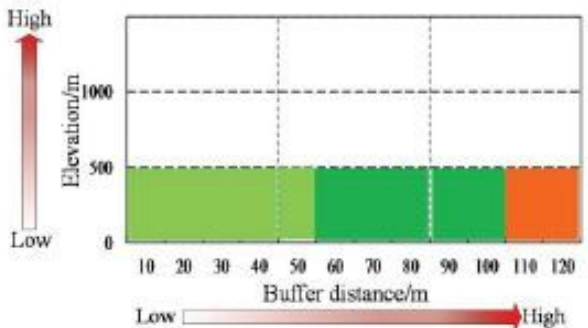

(a)1986 -2000

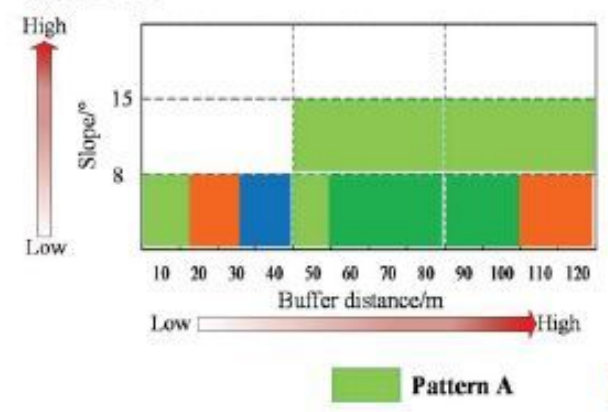

(b) $2000 \sim 2010$

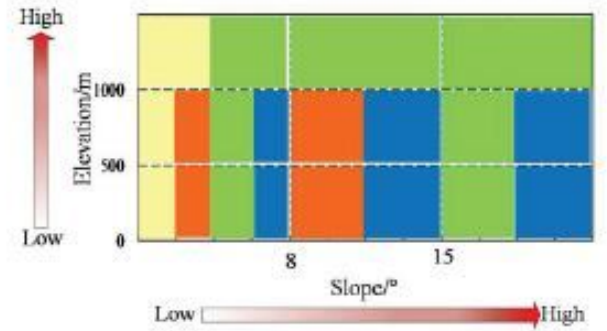

(b) $2000-2010$

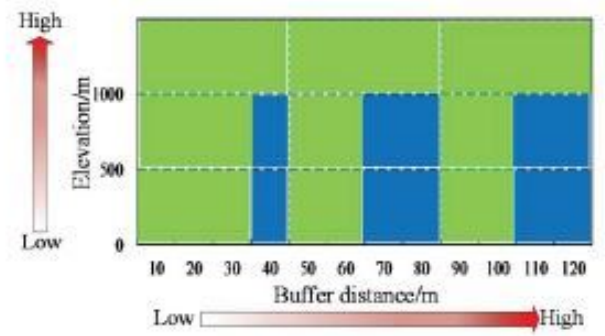

(b)2000-2010

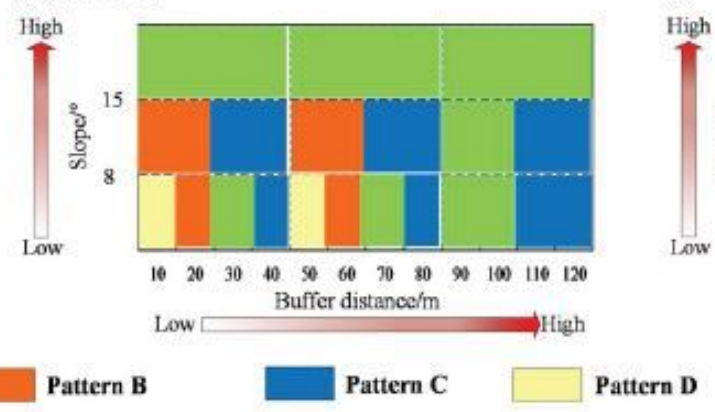

(c)2010 2017

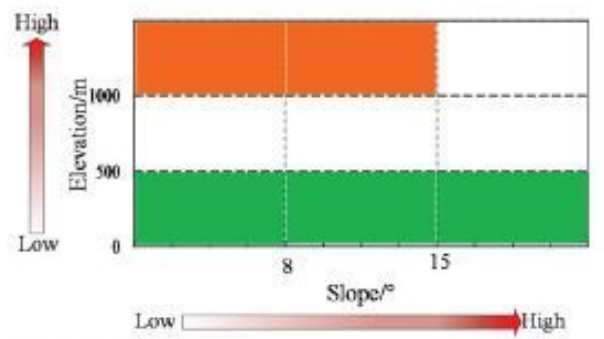

(c) 2010-2017

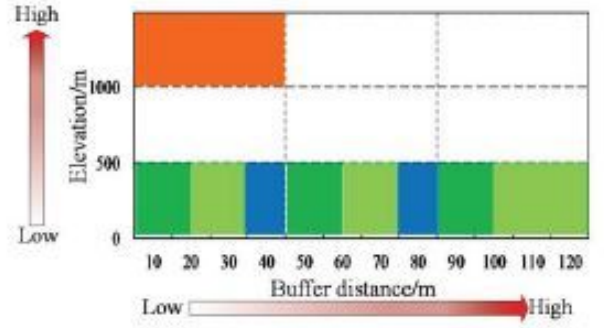

(c)2010-2017

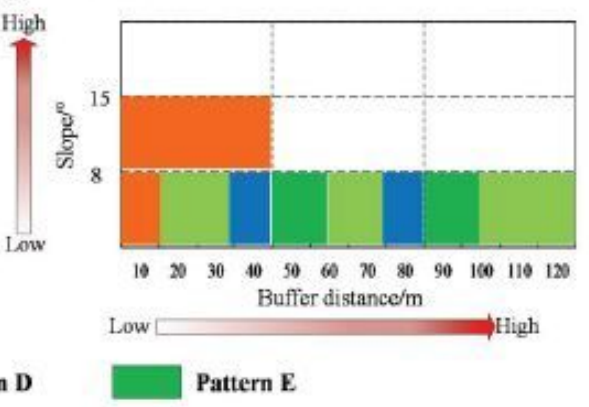


Figure 10

Landscape evolution model in a typical watershed of the TGRA

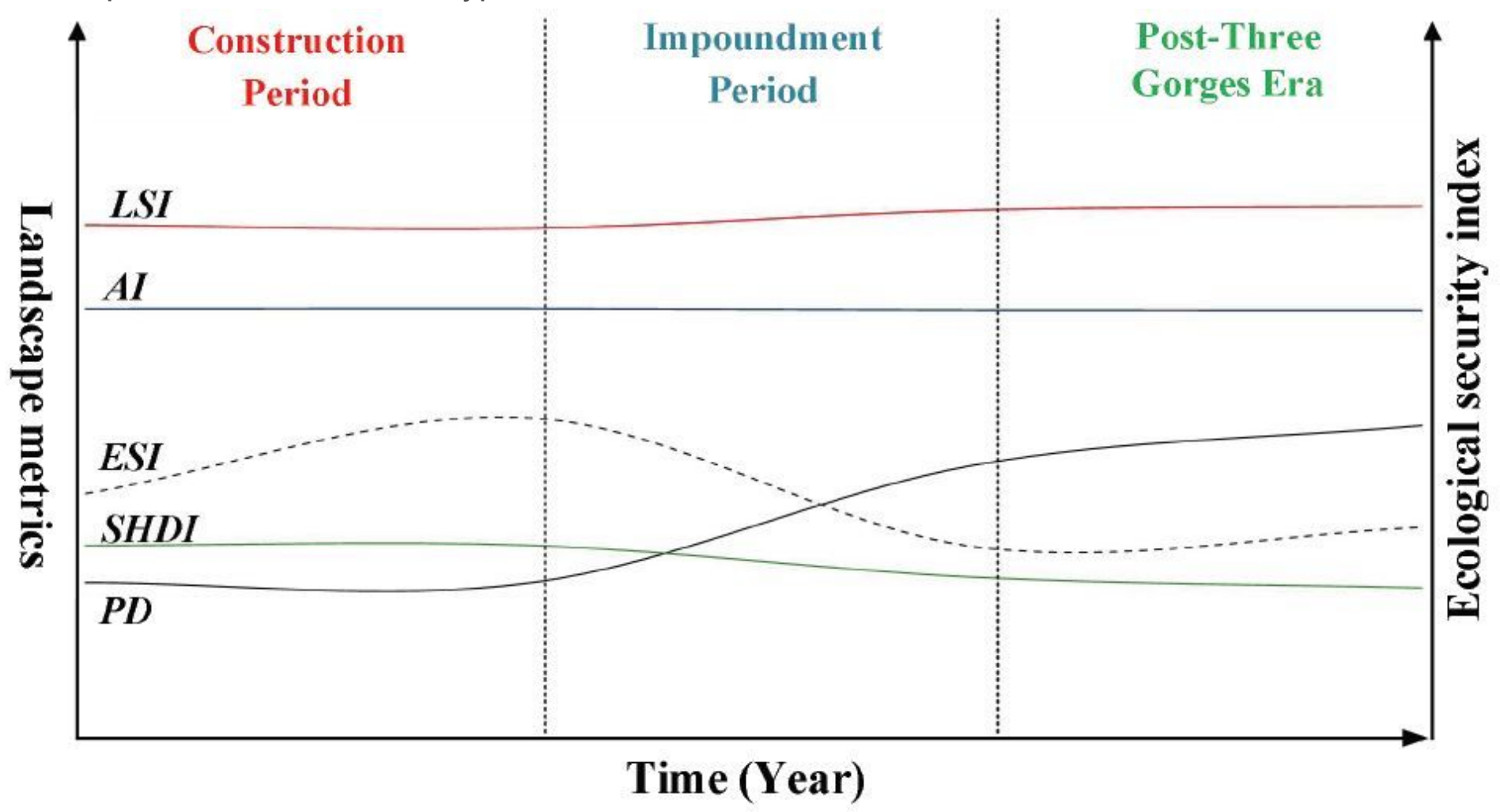

\section{Figure 11}

Change in landscape pattern indexes in the watershed
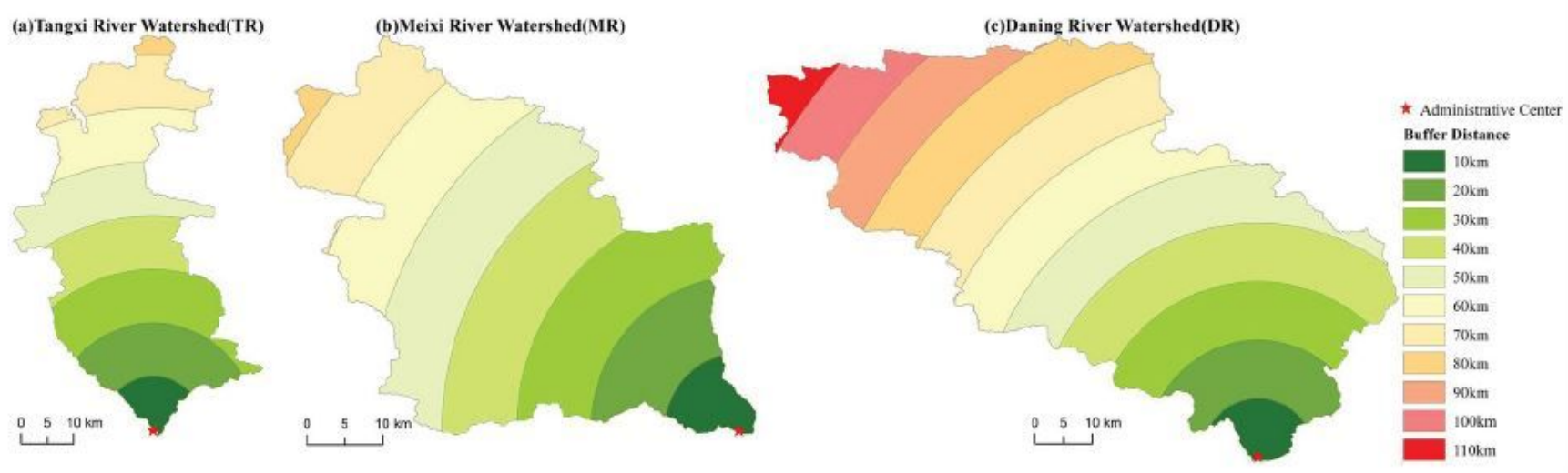

Figure 12

Setting up of watershed buffer zone Note: The designations employed and the presentation of the material on this map do not imply the expression of any opinion whatsoever on the part of Research Square concerning the legal status of any country, territory, city or area or of its authorities, or concerning the delimitation of its frontiers or boundaries. This map has been provided by the authors. 